\title{
HOW CANADIAN MUNICIPALITIES ARE(N'T) ENGAGING THE PUBLIC IN SMART CITY INITIATIVES
}

\author{
By \\ Lindsay Toth \\ BSc, McGill University, Montreal, 2012 \\ A Major Research Paper \\ presented to Ryerson University \\ In partial fulfillment of the requirements for the degree of \\ Master of Planning \\ in \\ Urban Development
}

Toronto, Ontario, Canada, 2019

(C) Lindsay Toth 2019 


\section{AUTHOR'S DECLARATION FOR ELECTRONIC SUBMISSION OF A MRP}

I hereby declare that I am the sole author of this MRP. This is a true copy of the MRP, including any required final revisions.

I authorize Ryerson University to lend this MRP to other institutions or individuals for the purpose of scholarly research.

I further authorize Ryerson University to reproduce this MRP by photocopying or by other means, in total or in part, at the request of other institutions or individuals for the purpose of scholarly research.

I understand that my MRP may be made electronically available to the public. 


\title{
HOW CANADIAN MUNICIPALITIES ARE(N’T) ENGAGING THE PUBLIC IN SMART CITY INITIATIVES
}

\author{
(C) Lindsay Toth 2019 \\ Master of Planning \\ in \\ Urban Development \\ Ryerson University
}

\begin{abstract}
The smart city concept is innovation in urbanism. Innovation is transformative, demanding the involvement of the public based on a belief that those who will be impacted by a decision have a right to be involved in the decision-making process. But smart city initiatives raise complex technical, privacy, economic, and intellectual property issues unlike those the public has been presented with before. This paper explores how Canadian municipalities are approaching this challenge by coding and analyzing applications to Infrastructure Canada's Smart Cities Challenge (SCC). The analysis reveals, among other findings, that municipalities engaged citizens directly as well as their representatives, leveraged previously-conducted engagement and conducted new engagement, and employed a range of engagement activities online and offline. Recommendations to Infrastructure Canada and municipal planners highlight the need for more public input on the technology solutions proposed, increased attention to the digital divide during engagement, and citizen involvement in all stages of open innovation.
\end{abstract}

Key words: Smart Cities Challenge, public engagement, open innovation 


\section{Acknowledgements}

Thank you to my supervisor, Dr. Pamela Robinson, for her encouragement and thoughtful edits.

Additional thanks are due to my family and friends for their support and understanding as I disappeared for days at a time close to deadlines for this paper.

This MRP was funded, in part, through research grants held by Dr. Pamela Robinson (SSHRC Grants: 892-2018-0046 and 895-2012-1023). 


\section{Table of Contents}

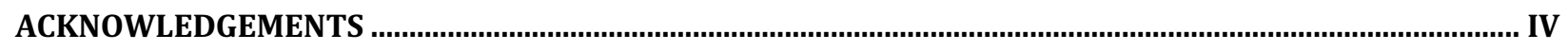

LIST OF TABLES ….................................................................................................................................. VII

LIST OF FIGURES.

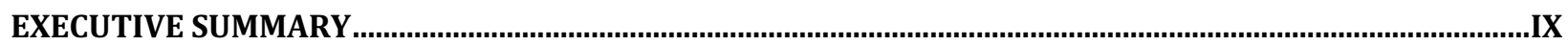

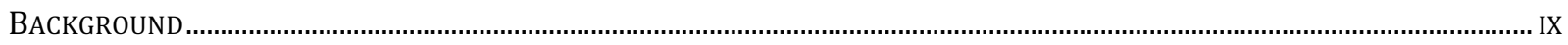

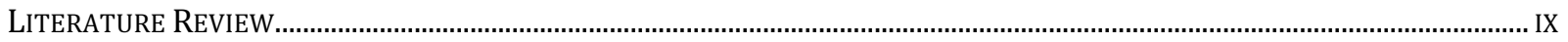

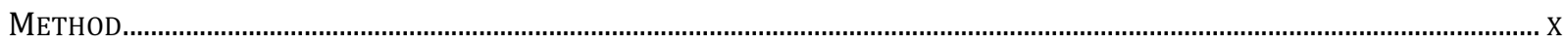

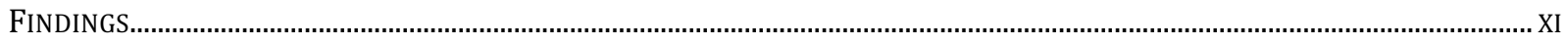

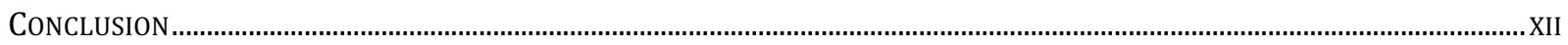

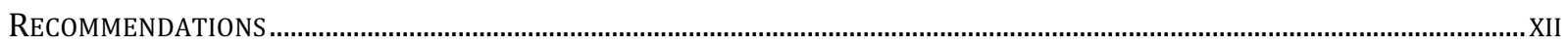

Recommendations for Infrastructure Canada ................................................................................................... xii

Recommendations for Municipal Planners ......................................................................................................... xiii

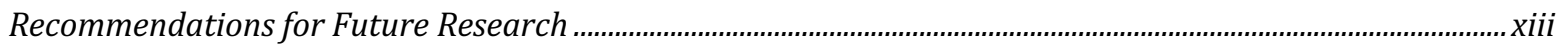

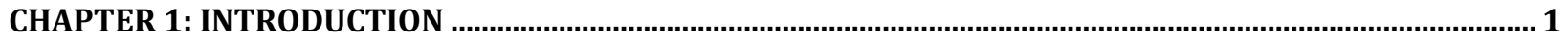

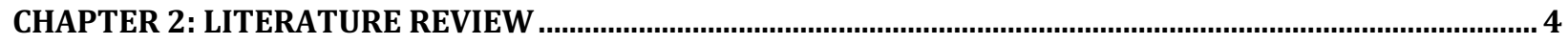

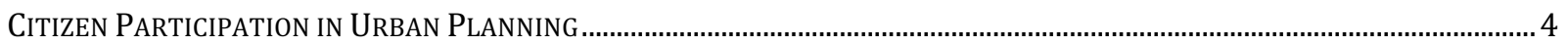

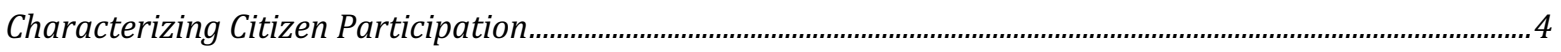

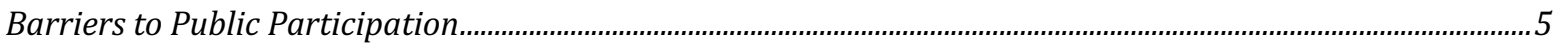

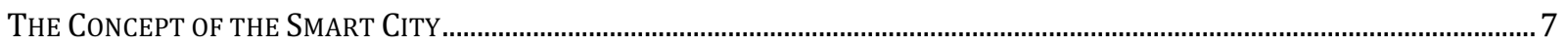

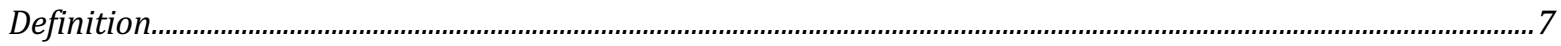

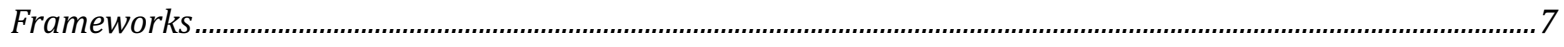

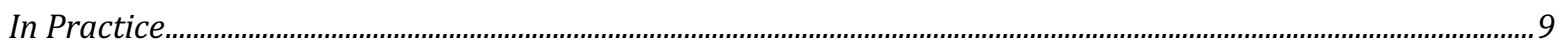

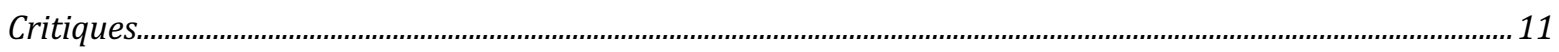

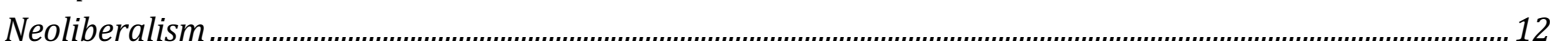

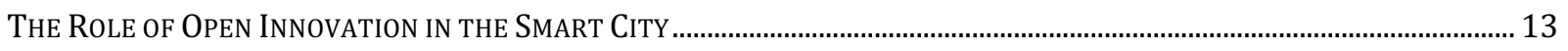

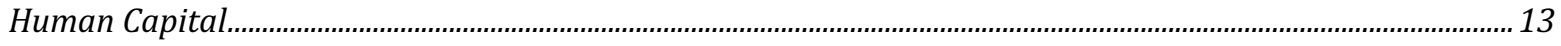

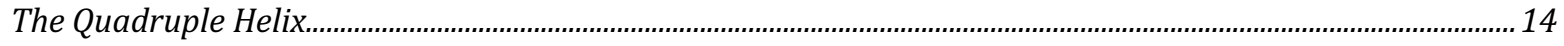

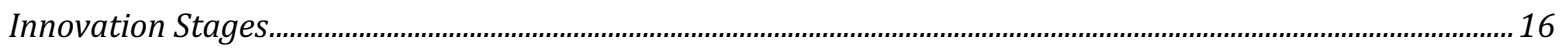

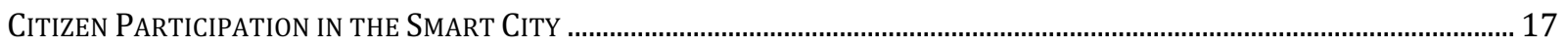

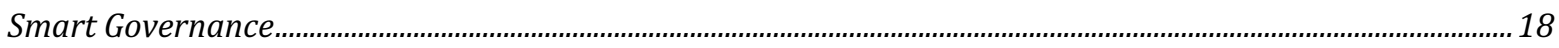

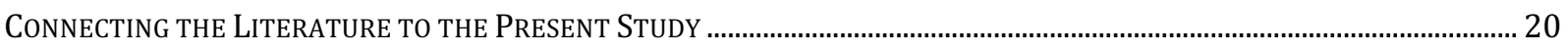

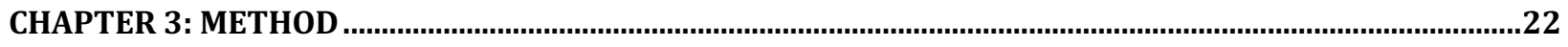

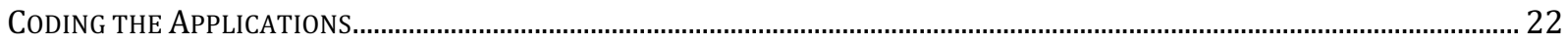

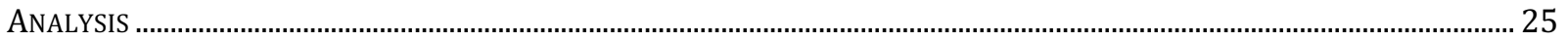

CHAPTER 4: PROBLEM INVESTIGATION/EVIDENCE AND FINDINGS .......................................................26

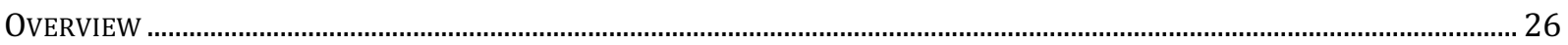

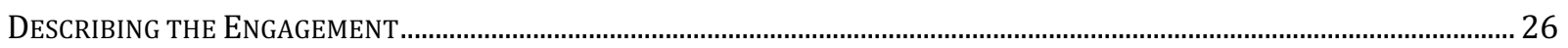

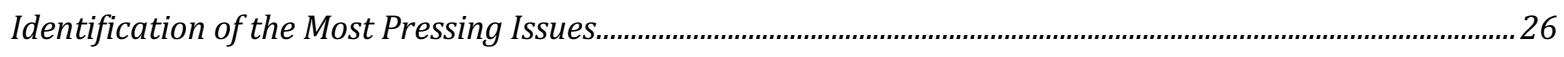

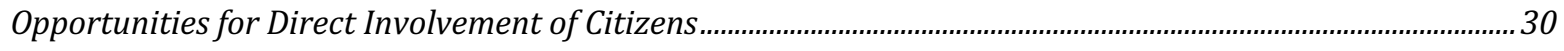

Making Use of New and Previously-Conducted Engagement .................................................................................... 32 


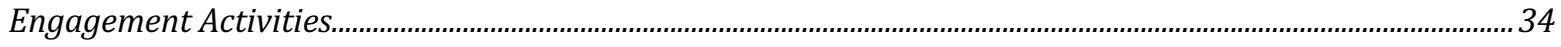

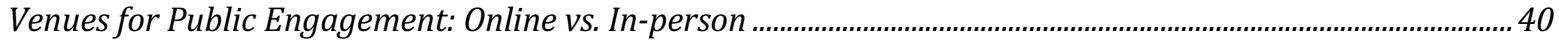

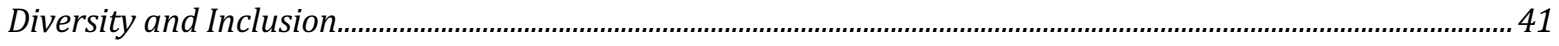

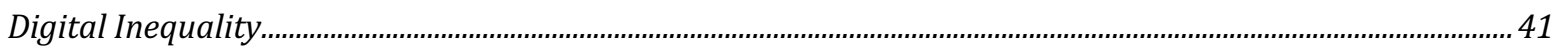

Collecting Geospatial Data ......................................................................................................................... 42

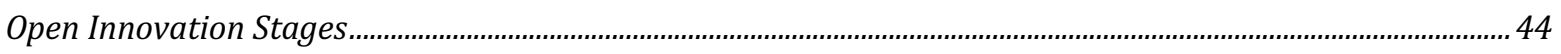

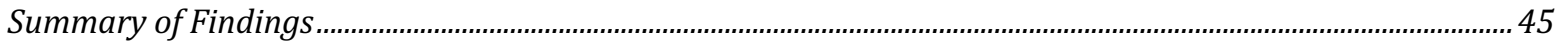

CHAPTER 5: CONCLUSION AND RECOMMENDATIONS FOR PRACTICE AND FUTURE RESEARCH .............47

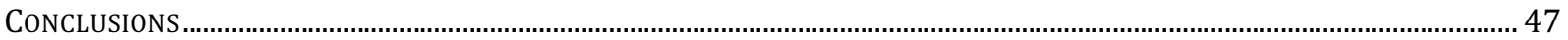

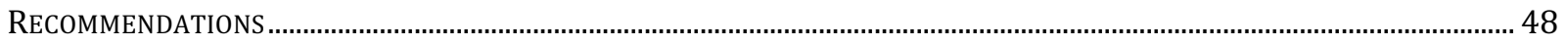

Recommendations for Infrastructure Canada .............................................................................................................. 48

Recommendations for Municipal Planners ............................................................................................................... 52

LIMITATIONS OF THIS RESEARCH...................................................................................................................... 54

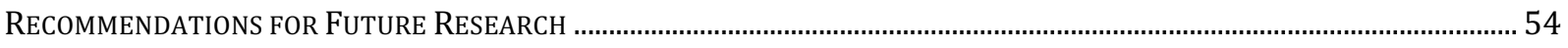

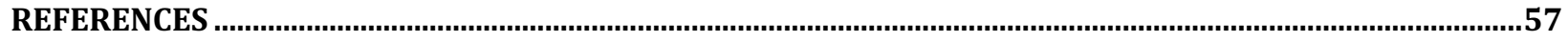

APPENDICES

APPendix A: List of Smart Cities Challenge FinalistS And Prize AMountS ............................................................. 62

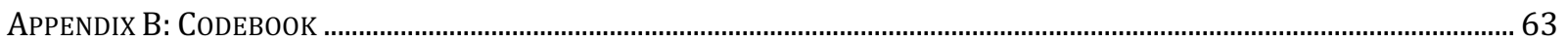




\section{List of Tables}

Table 1. Smart city framework by Giffinger et al. (2007) 8

Table 2. Smart Cities Challenge applications analyzed. 26

Table 3. Citizen involvement in identifying or defining the community's most pressing issues.

Table 4. Types of democracy built into the public engagement process.

Table 5. New and previously-conducted engagements.

Table 6. Engagement activities. 36

Table 7. Venue for public engagement. 40

Table 8 . Diversity and inclusion reflected in the design of public engagement.

Table 9. Reducing digital inequality.

Table 10. Collecting geospatial data.

Table 11. Citizen involvement in the five stages of open innovation. 


\section{List of Figures}

Figure 1. Ladder of citizen participation. (Source: Arnstein, 1969) 5

Figure 2. Smart City Initiatives Framework. (Source: Chourabi et al., 2012) 9

Figure 3. The transition of urban service development towards a sustainable 15 open innovation model. (Source: Paskaleva, 2011)

Figure 4. Scaffold of smart citizen participation. (Source: Cardullo \& Kitchin, 2018)

Figure 5. Top 5 Engagement Activities Completed by all Applicants.

Figure 6. Top 5 Engagement Activities Proposed by Finalists. 


\section{Executive Summary}

\section{Background}

In November 2017, Infrastructure Canada, a department of the Government of Canada, issued a Smart Cities Challenge (SCC) inviting municipalities and Indigenous communities to compete for substantial prizes to implement smart city initiatives that will address communities' most pressing problems (Government of Canada, 2017). Public engagement is a key component of the SCC. Municipalities were instructed to consult residents and stakeholders about pressing issues and incorporate what they heard into Challenge Statements. Municipalities also developed plans as to how they would continue to engage residents in the development and implementation of the final proposal. From 130 eligible applications, 20 finalists were selected and awarded $\$ 250,000$ to refine their proposals. The winning municipalities will be announced in May 2019 .

Based on a belief that those who will be impacted by a decision have a right to be involved in the decision-making process, governments should be engaging their pubic before and during smart city transformations (IAP2 Canada, 2018). There is a strong body of evidence around public participation in planning, but smart cities present new and unique challenges to public engagement and deserve specific attention from academia.

\section{Literature Review}

Smart cities arise when "investments in human and social capital and traditional (transport) and modern communication (ICT) infrastructure fuel sustainable economic growth and a high quality of life, with a wise management of natural resources, through participatory governance” (Caragliu, Del Bo \& Nijkamp, 2011, p.6). Hundreds of smart city initiatives are underway in small, medium, and large cities around the world (Lee, Hancock \& Hu, 2014). A 
small study of actually-existing smart cities in Canada showed variation in the extent of public engagement between cities (Bloom, Lauriault \& Landry, 2018). Critiques of the smart city focus on the unfounded assumptions that technological solutions are always positive and desired by the public, concerns about data ownership and privacy, and the ethics of using welfare dollars to attract private capital investment (Hollands, 2008; Zuboff, 2013; Sauter, 2018; Wylie 2018).

The dominance of neoliberalism prompted the rise of the smart city concept. There are two roles for the public that are compatible with a neoliberal ideology: citizen-as-consumer and co-producer. Engaging citizens as co-producers is accomplished through open innovation. Open innovation recognizes the value of collaboration and that pooling different knowledge, skills, and experiences from outside the firm produces superior innovations (Chesbrough, 2003). Desouza et al. in 2009 outlined five stages of the innovation process: 1) Idea Generation and Mobilization, 2) Advocacy and Screening, 3) Experimentation, 4) Commercialization, and 5) Diffusion and Implementation. Citizen involvement throughout all stages of the innovation process is consistent with the upper rungs on Arnstein's (1969) Ladder of Citizen Participation. The redistribution of power results in a productive and meaningful experience for the public and governments (Arnstein, 1969).

\section{Method}

The purpose of this study is to understand the extent to which the SCC catalyzed public engagement and to describe how Canadian municipalities are engaging their citizens around smart city initiatives. Of 130 valid applications, 102 were available for analysis. After reading the Challenge Statement, Question 5 (which related specifically to public engagement) was coded according to several variables that emerged from the literature review. Variables included, among others, efforts to reduce the digital divide during public engagement, reflecting diversity and 
inclusion in the design of engagement, and citizen involvement in the five open innovation stages (described by Desouza et al., 2009). To reveal overall trends in the data, frequency tables were prepared for each of the variables, with finalists and non-finalists distinguished.

\section{Findings}

These results provide insight into how Canadian municipalities are engaging the public in smart city initiatives. In general, Canadian municipalities are:

- offering participation opportunities directly to citizens, in addition to their representatives;

- leveraging previously-conducted public engagement and supplementing it with new engagement specific to smart cities;

- engaging the public most often via surveys, public meetings, social media, written submissions, and stakeholder meetings, both online and in-person;

- too often not making an explicit effort engage seldom heard/hard to reach groups;

- not working to reduce digital inequality throughout the public engagement process;

- choosing not to collect or use geospatial data; and

- not involving citizens fully in the open innovation process.

The findings also highlight some key differences between municipalities that were successful in the Challenge (advancing to the finalist phase) and those who were unsuccessful. Notably, compared to non-finalists, finalist municipalities more frequently conducted new public engagement specifically for the purposes of the SCC, made efforts to reduce digital inequality during public engagement, and involved citizens in all five stages of the open innovation process. 


\section{Conclusion}

The present study revealed that Canadian municipalities met most of the SCC's minimum requirements for public engagement. They employed a broad range of engagement activities, including some highly creative techniques. There was opportunity for improvement in municipalities' efforts to engage seldom heard groups, by recognizing that barriers to participation exist beyond a lack of awareness.

Canadian municipalities struggled to help the public navigate the additional complexity a smart city approach brings. There was a widely-held assumption that citizens will support any technology solution that solves their pressing issue. Therefore, municipalities did not provide sufficient access to information to allow for a public discourse about the benefits and risks of specific technology solutions. Municipalities also demonstrated uncertainty about how to address digital inequality during public engagement and how to connect place with the smart city framework. Analysis of public involvement in the five stages of open innovation showed that coproduction stalls in the later stages. Municipalities are typically not involving the public at all in the Commercialization or Diffusion and Implementation stages. A significant amount of the difficulty encountered by municipalities can be attributed to the fact that many are attempting a smart city approach for the first time. There is much to be learned from their early experiences.

\section{Recommendations}

\section{Recommendations for Infrastructure Canada}


1. Revise instructions to municipalities and application questions to spell out exactly what is expected of applicants in terms of public engagement.

2. Provide education and resources to municipalities on public engagement for smart city initiatives.

3. Develop a new program to reduce digital inequality across Canada.

4. Create a "menu" of public engagement activities used in previous cycles of the SCC to inspire municipalities.

5. Sustain the Smart Cities Community Support Program.

\section{Recommendations for Municipal Planners}

6. Remain vigilant about the public interest.

7. Use public engagement as an opportunity to reduce digital inequality.

8. Don't forget about place.

\section{Recommendations for Future Research}

Future research should be designed to develop an empirical understanding of successful citizen involvement in smart city innovation ecosystems and explore best practices. The evidence base could also benefit from an improved understanding of Canadians' actual level of knowledge of the smart city concept. I suggest that the SCC continue to be studied, specifically to address the question of whether the SCC helped to catalyze better engagement. 


\section{Chapter 1: Introduction}

Cities are both a source and subject of innovation. Abundant human capital combined with agglomerations of creative industries are ingredients for novel ideas (Caragliu, Del Bo \& Nijkamp., 2011; Florida, 2002). Innovation can be disruptive for cities. From the introduction of the automobile, the rise of the internet, and now applications that facilitate a sharing economy, the form and function of cities has been shaped by technological change. Sometimes citizens advocated for and welcomed this change, sometimes not. Sometimes this change has been positive, other times it has injured our health, prosperity, equity, and social cohesion. Innovation and opportunities to transform cities continue at an unprecedented rate. In democratic societies, understanding where citizens fit in innovation is crucial.

These days, urban areas are the target of all sorts of innovations aimed at increasing efficiency and improving quality of life for city dwellers. A "smart city" is the result of these innovations. In November 2017, Infrastructure Canada, a department of the Government of Canada, issued a Smart Cities Challenge (SCC) inviting municipalities and Indigenous communities to compete for substantial prizes to implement smart city initiatives that will address communities' most pressing problems (Government of Canada, 2017). One \$50-million prize, two \$10-million prizes, and one \$5-million prize will be awarded through the SCC. From 130 eligible applications submitted (“applicant phase”), 20 finalists have been selected and awarded \$250,000 to refine their proposals ("finalist phase"). The winners will be announced in May 2019. 
Infrastructure Canada identifies public engagement as a key component of the SCC. Municipalities ${ }^{1}$ were instructed to consult residents and stakeholders about pressing issues and incorporate what they heard into Challenge Statements. In their applications, municipalities were asked to outline how they would continue to engage residents in the development and implementation of the final proposal. Applications were evaluated by the SCC jury for evidence that public and stakeholder engagement informed the Challenge Statement, that engagement had broad participation and included diverse voices, and that there was an adequate plan to sustain engagement throughout the development and implementation of the initiative. This component of the application accounted for 15 percent of the total points available to be scored.

An interesting feature of the SCC is that municipalities were required to post full versions of their applications online, though some have since removed these from their websites if they were not selected as finalists. Infrastructure Canada also posted bilingual summaries of all applications online. This level of transparency holds municipalities accountable to their publics, as well as provides opportunities for knowledge sharing between municipalities and encourages dialogue among stakeholders.

In tandem with the SCC, Infrastructure Canada provided funding to Canadian non-profit organization Evergreen to facilitate knowledge sharing, networking, and capacity building for all Canadian municipalities around smart city approaches (Government of Canada, 2018a). Evergreen was selected through a competitive application process and may receive up to $\$ 4.6$ million over two years. Working with Open North and other partners, Evergreen developed the

\footnotetext{
${ }^{1}$ For simplicity, throughout this document I will refer to applicants of the SCC as "municipalities" although applicants may also be groups of municipalities and/or Indigenous communities.
} 
Community Solutions Network to provide advisory services, host in-person events across the country, and offer an online Smart Cities Portal with resources (Evergreen, 2019).

This research explores the extent to which the SCC catalyzed public engagement ${ }^{2}$. It investigates how communities engaged and plan to continue engaging residents, how engagement shaped SCC applications, and if there are patterns relating to community engagement and the applicant's success in the SCC. Recommendations informed by the aforementioned analysis will be directed to Infrastructure Canada to extend the impact of the SCC in future competition cycles, and to municipal planners to improve the quality of public engagement around smart city initiatives. Future research directions to round out the body of evidence will also be proposed.

This research is important for two reasons. First, there is a clear research-to-practice pathway. This is the first cycle of the Smart Cities Challenge, but Infrastructure Canada has committed \$300-million over 11 years. The SCC can evolve to produce better results. Hence, it is appropriate to evaluate the success of the SCC in motivating meaningful public engagement and make recommendations for improvement. Second, this topic represents a knowledge gap. Although there is a strong body of evidence around public participation in planning, smart city initiatives present new and unique challenges to public engagement. Smart city initiatives raise complex technical, privacy, economic, and intellectual property issues unlike those the public has been presented with before. There are also digital inequities (the "digital divide") which require creative solutions to ensure diverse representations of public opinion. Therefore, how to do public engagement around smart city initiatives well is a worthy topic of study.

${ }^{2}$ Readers should note that this research was completed from October 2018 to March 2019; after finalists were selected, but prior to the submission of their full proposals and the announcement of winners. The analysis therefore focuses on the applicant phase of the SCC. 


\section{Chapter 2: Literature Review}

\section{Citizen Participation in Urban Planning}

\section{Characterizing Citizen Participation}

Citizen participation encompasses a range of activities planners and decision makers use to gather information on preferences directly from involved members of the public. It is grounded in a belief that those affected by a decision have a right to be involved in the decision-making process (IAP2 Canada, 2018). In 1969, Sherry Arnstein authored a paper that presented a typology of citizen participation, arranged in a ladder pattern with each successive rung representing a higher degree of citizen power. The Ladder of Citizen Participation (see Figure 1), was provocative at the time and remains influential. Arnstein was critical of how governments were involving the public, especially the poor, in the planning process and urban regeneration programmes. She wanted to show that there were gradations to citizen participation and argued that "participation without redistribution of power is an empty and frustrating process for the powerless" (p.216).

The lowest rungs of the ladder are seen as non-participation. Manipulation describes efforts by governments to educate or reform the "have-nots". Therapy stems from a very outdated belief that powerlessness is a symptom of mental illness. Public participation at this rung is a type of unwelcome group therapy. Arnstein describes the middle rungs of the ladder as degrees of tokenism. Informing means a one-way flow of information to citizens about their rights, responsibilities, and options. Consultation is the first time on the ladder citizens are invited to share their opinion, usually through surveys or public meetings. Placation gives the illusion of meaningful participation to citizens though tokenism is still apparent. The three highest rungs on the ladder is where citizens share decision-making duties with the dominant power-holders. In 
partnership, power is redistributed through negotiation, but citizens remain with minority control. Citizens get majority control at the delegated power rung but are still dependent on governments for resources. The top rung represents citizen control, where there are no intermediaries and citizens have full policy and managerial control.

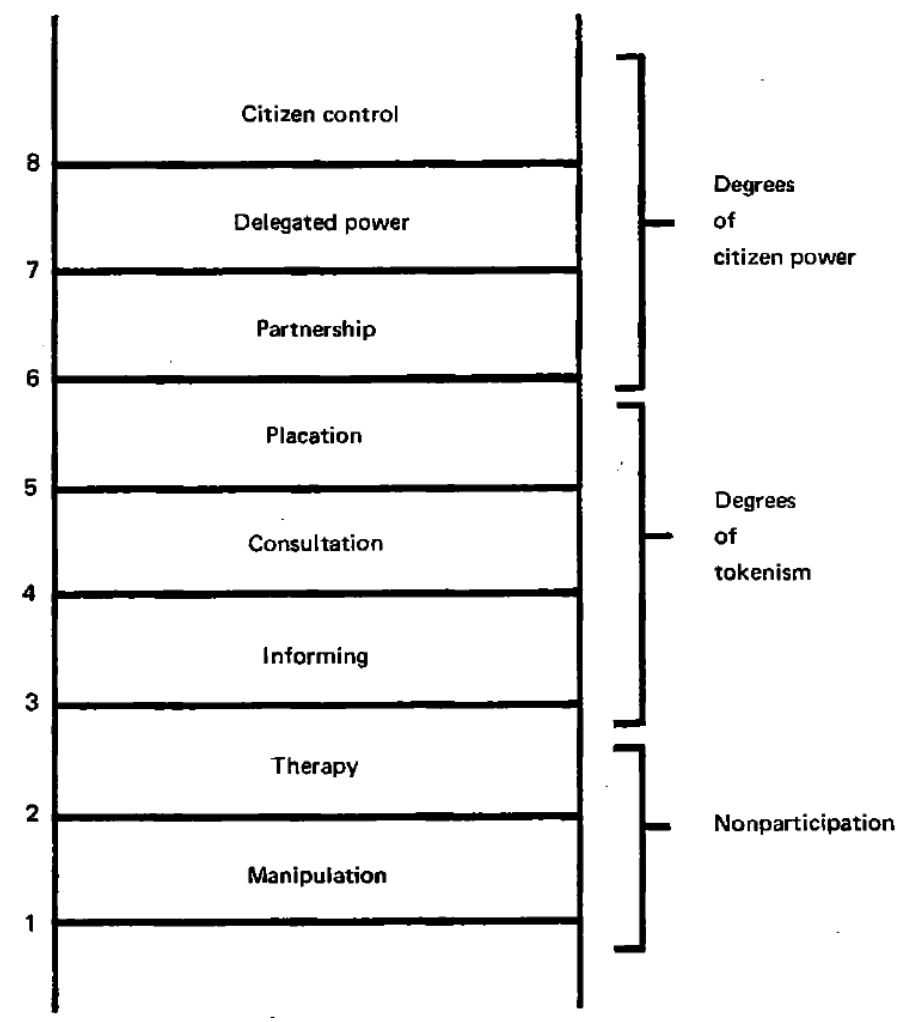

Figure 1. Ladder of citizen participation. (Source: Arnstein, 1969)

\section{Barriers to Public Participation}

In public participation, representativeness of the deliberating group is necessary to ensure all perspectives are considered and power and resources are distributed equitably (Karpowitz \& Raphael, 2016). Anything that limits the participation of a marginalized group can cause harm (Karpowitz \& Raphael, 2016). Civic participation comes with benefits and costs. At minimum, participation requires time, money, and civic skills (Brady et al., 1995). Specific population groups 
face additional barriers to participation. For example, older adults are dissuaded from civic participation by poor health, limited mobility, low income, and the societal perception that they have nothing to offer (Kart \& Kinney, 2001; Thorson, 2000). Therefore, citizens who participate are more likely to be middle-aged, employed in professional occupations, mid-to-high income, and high school graduates (Pattie, Seyd \& Whiteley, 2003). In other words, without checks and balances public participation tends to capture and promote the voices of society's most powerful.

Karpowitz \& Raphael (2016) offer the following advice for planning inclusive public engagement:

Forums that aim to speak for the people as a whole should practice inclusion by opening their doors to all while simultaneously being sensitive to the effects of self-selection, making sure that those who are least likely to participate are affirmatively recruited. When such holistic forums cannot accommodate everyone and therefore must limit participation, a stratified random sample that ensures a critical mass of those who are usually underrepresented in public deliberation is the key to ensuring that all voices are heard sufficiently. (p.16)

A community development approach is commonly used to address marginalized communities' barriers to participation by strengthening skills, abilities, and leadership (Montesanti et al., 2016). The logic is that enhanced capacity helps marginalized communities surmount barriers to public participation and then offers continued benefits in the future. Although community development often works, public engagement specialists should be mindful that this approach assumes an underlying willingness of marginalized populations to participate (Montesanti et al., 2016). Cultural values and beliefs around the topic of public engagement (e.g. health, technology, parks, public transit, etc.) may impact the degree to which marginalized communities see value in civic participation (Montesanti et al., 2016). 


\section{The Concept of the Smart City}

\section{Definition}

Beyond its catchy name, the concept of the smart city is "fuzzy" (Caragliu et al., 2011). Supplanting predecessors including the "wired city", "knowledge city”, "digital city", and "information city", the smart city has become the aspiration for municipalities around the world, albeit without a common definition (Cocchia, 2014). The common thread between these terms is the "link[ing] together of technological transformations with economic, political and sociocultural change" (Hollands, 2008, p.305). Earlier understandings of the concept centred on internet connectivity and virtualization of relationships and services (Cocchia, 2014). Although technology is still a major component, newer definitions regard people and their quality of life as the principal motivator of change (Cocchia, 2014). For the present paper, I prefer the definition set out by Caragliu et al. (2011):

[A city is smart when] investments in human and social capital and traditional (transport) and modern communication (ICT) infrastructure fuel sustainable economic growth and a high quality of life, with a wise management of natural resources, through participatory governance. (p.6)

This definition is favoured because it is essentially a logic model for change and improvement in urban areas; it describes required inputs, processes, and expected outcomes. It also identifies a prominent role for citizens.

\section{Frameworks}

Caragliu et al.'s definition of a smart city is a nod to a theoretical framework developed by Giffinger et al. (2007) at the Centre of Regional Science at the Vienna University of Technology. The framework identifies smart economy, smart people, smart governance, smart mobility, smart environment, and smart living as the building blocks of a smart city (Table 1). The main benefit of 
this framework is that it aligns with the traditional activities of urban development and if therefore easily understood by stakeholders. Citizens are included in four of the six components: smart people, smart governance, smart mobility, and smart living.

Table 1. Smart city framework by Giffinger et al. (2007)

\begin{tabular}{|l|l|}
\hline Component of a Smart City & Definition \\
\hline Smart Economy & $\begin{array}{l}\text { The city features agglomerations of industries in the } \\
\text { fields of information and communication technologies as } \\
\text { well as other industries employing ICT in their } \\
\text { production processes. }\end{array}$ \\
\hline Smart People & $\begin{array}{l}\text { Citizens have achieved a high level of educational } \\
\text { achievement and there is the presence of academic } \\
\text { institutions. }\end{array}$ \\
\hline Smart Governance & $\begin{array}{l}\text { There is a strong connection between the city } \\
\text { government and its citizens, facilitated through new } \\
\text { channels of communication (i.e. e-governance). }\end{array}$ \\
\hline Smart Mobility & $\begin{array}{l}\text { The city implements modern transport technologies to } \\
\text { improve urban traffic and citizens' mobility. }\end{array}$ \\
\hline Smart Environment & $\begin{array}{l}\text { The city is sustainable through its efficient management } \\
\text { of energy, waste, etc. }\end{array}$ \\
\hline Smart Living & Citizens have a high quality of life. \\
\hline
\end{tabular}

Building off Giffinger et al.’s seminal work and incorporating research findings from a number of associated fields, Chourabi and colleagues (2012) created an integrative framework (see Figure 2) to understand smart city initiatives. This framework shows the factors influencing and influenced by smart city initiatives, as well as differentiates the level of influence of each factor. Technology, policy, and management/organization are closely tied to smart city initiatives. Secondary factors including economy, built infrastructure, natural environment, governance, and people and community are also involved. Nam and Pardo (2014) view smart city initiatives as innovation in the three core factors. Technological innovation supplies the tools smart cities need, 
organizational innovation creates capacity to manage smart city initiatives, and policy innovation provides the normative drive to which smart city initiatives may respond (Nam \& Pardo, 2014). In terms of the present study, it is important to note this framework shows that people and communities will bear the impacts, whether positive or negative, of smart city initiatives. However, it also highlights that an engaged and empowered public could have far-reaching influence on the smart city. The integration of people and communities and the bi-directional influence in Chourabi et al.'s framework shows the evolution in thinking around the need to involve citizens in smart city initiatives, beyond considering smart people as a discrete and separate component in Giffinger's earlier framework.

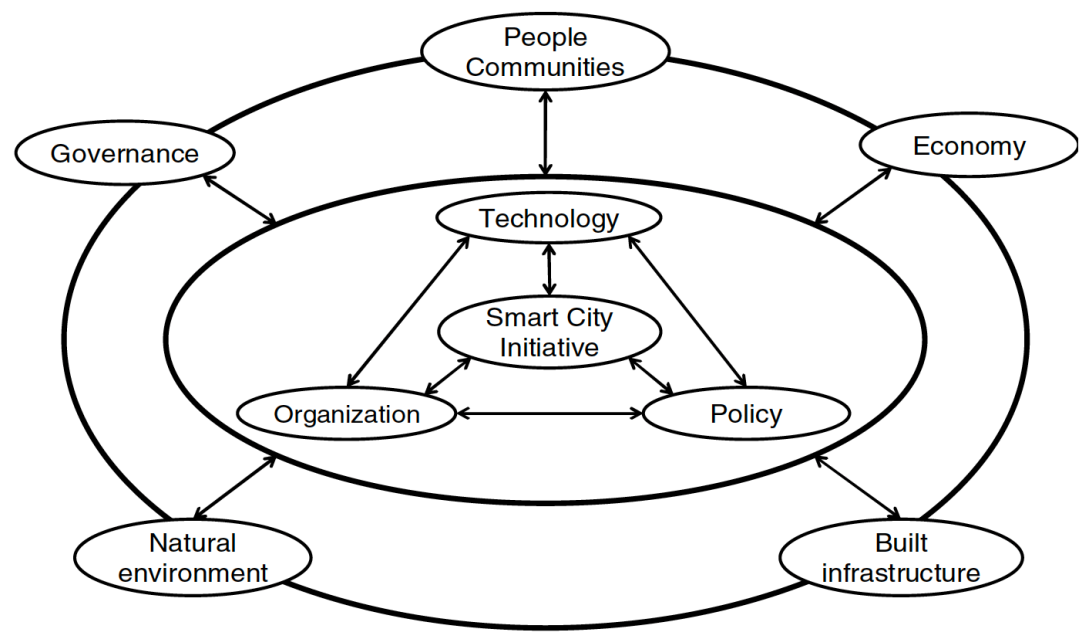

Figure 2. Smart City Initiatives Framework. (Source: Chourabi et al., 2012)

\section{In Practice}

Although the concept of smart cities is still taking shape in the theoretical literature, the public and private sectors are eagerly implementing the potentialities of ICTs and computing to solve the pressing needs of urban areas (Tang, 2018). Currently, hundreds of smart city initiatives are underway in small, medium, and large cities around the world (Lee, Hancock \& Hu, 2014). For example, in Canada, Quebec City has installed sensors on snow clearing machinery, integrated 
different information systems related to infrastructure management, made city data open, and is providing free wireless internet in public spaces (Alawadhi et al., 2012). In Toronto, Waterfront Toronto (a public agency created by the Government of Canada, Province of Ontario, and the City of Toronto) has partnered with Sidewalk Labs (an Alphabet company, sister company to Google) to create a Master Innovation and Development Plan to guide the development of a 12acre parcel of waterfront real estate as a smart community pilot, with the eventual goal to extend the innovations across a much larger (800 acre) underdeveloped site nearby (Sidewalk Toronto, n.d.).

Open North, a Canadian nonprofit with expertise in open data and civic technology, reviewed the public engagement around actually-existing Canadian smart cities in four municipalities: Edmonton, Montreal, Guelph and Ottawa (Bloom, Lauriault \& Landry, 2018). The cities opted to pursue smart city initiatives for a variety of reasons, broadly stemming from internal political leadership and external economic pressures. Three of the municipalities (Edmonton, Montreal, and Ottawa) have formal smart city strategies. The extent of public engagement differed between cities. Montreal engaged the public directly to identify pressing issues and suggest technology solutions. Edmonton and Ottawa did not directly engage the public but attempted to discern the public interest by proxy; Edmonton leveraged public input from previous initiatives and Ottawa consulted stakeholders. All four cities in the Open North study encouraged the formation of open innovation ecosystems, for example through accelerator programs and public-private partnerships to pilot technologies.

Asia and Europe have more smart city initiatives than the Americas (Cocchia, 2014), with geographic differences in types of initiatives emerging as well. Asian smart city initiatives focus mostly on "hard" domains, such as natural resources and energy, transportation, and buildings. In Europe, initiatives focusing on "soft" domains are common, specifically those around quality 
of life, economy, and government. Geographic differences are hypothesized to be a result of different pressing issues, regional policies, and economic health (Neirotti et al., 2014). Based on this, one might expect that cities are guided by their unique local contexts and therefore would be implementing a substantially varied set of smart city initiatives. But, Tang's (2018) cluster analysis of global smart city plans revealed most are surprisingly similar. The author attributed this to the harmonizing effect of the marketing of ICT products and services by IT vendors, the advocacy of various roadmaps and migration paths by consultancies and non-governmental organizations, and the implementation of national guidelines by federal governments. This is not necessarily a disheartening finding, as open standards and the use of commercially-available technology facilitates transfer of ideas to other cities.

\section{Critiques}

To temper the hype surrounding the concept of smart cities, Hollands (2008) offers some critiques. First, the self-congratulatory label "smart" may lead to overlooking or underestimating potential negative effects of new technologies by governments and the public. Second, the excitement around smart cities is creating a strategic bias, which may blind municipalities from alternative avenues of promising urban development. Third, a business-led model of urban development in a global market with mobile capital could be a risky bet for municipalities. Finally, smart cities projects could deepen social inequity through gentrification and by diverting welfare dollars to attract capital and partnerships. Hollands points out that the marketing of smart cities often refers to "transformational change". An implicit assumption in this is that the urban public agrees to this transition and that the change is positive. It is essential that urban planners and policy makers step back and test this assumption in each context. 
Other critics raise concerns about privacy and data protection in the smart city. Smart cities utilize highly invasive technologies including interconnected sensors, Internet of Things (IoT), mobile applications, CCTV cameras and wearables. Zuboff (2013) asserts that unless mediated by restrictions and sanctions, every digital application that can be used for surveillance and control will be used for surveillance and control, regardless of its originating function. Red flags ought to raise when technology companies push for regulatory exemptions (Sauter, 2018). Additional challenges in Canada include "a lack of informed consent models for data collection both online and in public spaces, and legislative frameworks that do not provide consideration or process for collective data ownership, mass consent and privacy as a public good" (Wylie, 2018). Overall, this is an arduous situation that demands new forms of data governance at least as innovative as the other aspects of smart cities (Clement, 2018).

\section{Neoliberalism}

The rise of the smart city concept was made possible by the dominance of neoliberalism in urban areas. Neoliberalism proposes market mechanisms and managerial solutions to urban problems. The public interest is advanced by means of privatization, lean government, and market deregulation (Grossi \& Pianezzi, 2017). Historically, social and political considerations have decided the range of goods and services governments provide, and the prices charged (OECD/Eurostat, 2018). The introduction of private actors into the delivery of municipal services brings profit considerations to the fore. Cowley et al. (2018) argue that this causes urbanization to become a business model rather than a model of social justice. Through privatization, firms view city infrastructure as an "alternative asset class" from which maximum returns must be extracted (Morozov \& Bria, 2018). This could lead to chronic underinvestment. 
On an individual level, neoliberalism emphasizes personal autonomy and taking responsibility for one's life choices (the entrepreneurial self) (Cardullo \& Kitchin, 2018). This tends to cast citizens within the smart city as consumers, who selectively acquire services through purchases or swapping of personal data (Cardullo \& Kitchin, 2018). Neoliberalism values consumer choice, but in the smart city that choice may be an illusion. The smart systems and services on offer are largely predetermined before they reach the consumer, with only tweaks permitted (Cardullo \& Kitchin, 2018). Choice is also constrained by the monopolies enjoyed by just a few providers of smart city products and services (Cardullo \& Kitchin, 2018). Citizen-asconsumer is not the only role for the public that is compatible with a neoliberal ideology, as discussed in the next section.

\section{The Role of Open Innovation in the Smart City}

\section{Human Capital}

Human capital is the skills and competencies embedded in an individual or possessed collectively by a population (Appio, Lima \& Paroutis, 2018). Smart city development is dependent on innovation, and innovation is dependent on human capital. The presence of a vast number of creative (highly educated) professionals is positively associated with urban wealth, suggesting that successful cities pay attention to recruitment and retention of their human capital (Caragliu et al., 2011). Human capital is mobile and there is evidence of spatial clustering over time in cities providing high standards of living, health and leisure infrastructure, quality transportation networks, and the diffusion of ICTs (Appio et al., 2018; Caragliu et al., 2011; Florida, 2002). This evidence suggests the presence of a positive feedback cycle: municipal investments in human capital can spur smart city innovation, which improves the quality of life in the city, which 
attracts human capital, and so on. A public policy agenda that balances the technological and human aspects of smart city development is needed.

\section{The Quadruple Helix}

The smart city concept is innovation in urbanism. Municipalities vying for smart city status borrow innovation processes originally developed by industry. For a long time, innovation processes were tucked away in private sector firms' research and development departments. Market intel and new product or service ideas were carefully guarded intellectual property. In 2003, Chesbrough described a new kind of innovation process "based on a landscape of abundant information, which must be used readily" (p.37). Open innovation, as Chesbrough coined it, recognizes the value of collaboration and that pooling different knowledge, skills, and experiences from outside the firm produces superior innovations (Chesbrough, 2003). The shift from closed to open innovation in the private sector occurred due to an increase in the number and mobility of knowledge workers (which made it difficult for firms to control their proprietary ideas and expertise), the availability of venture capital and the resulting start-up culture (which meant smart people were going at it alone and typically not reinvesting the profits into new innovation), and the advancement of ICTs (which made broad sharing of information and ideas easier and less expensive). Especially in the field of urban technology, industry is now seeking ideas and collaboration from governments, public agencies, and the public.

As a result of collaboration with the private sector, public sector innovation is changing. Governments differ from private sector firms because they do not charge economically significant prices for their goods and services (OECD/Eurostat, 2018). Instead, governments make choices based on political and social considerations. The absence of a market makes measuring innovation outcomes challenging and unreliable. Governments, unable to demonstrate a strong link between 
innovation and positive outcomes, have less incentive to innovate and opt to minimize risk (OECD/Eurostat, 2018). Collaboration with the private sector introduces a market; the citizen becomes a consumer. Aggregated economic outcome measures become possible and a business case can be made for innovation in the public sector, while still achieving political and social goals with the same certainty as before.

The quadruple helix refers to an open innovation system which includes industry, universities, public authorities and end-users (Schuurman et al., 2012). In the smart city, the quadruple helix is realized through Public-Private-People Partnerships (PPPPs). In PPPPs, citizens are welcomed as co-producers of municipal good and services, a "new way for citizens to share not only in the design but also in the delivery of services and contribute their own wisdom and experience in ways that can broaden and strengthen services and make them more effective" (Paskaleva, 2011). Open innovation is a tool that can be deployed strategically by municipalities to align interests and promote a high quality of life. Figure 3 illustrates how open innovation transforms public service policy to a system of co-production in the smart city.

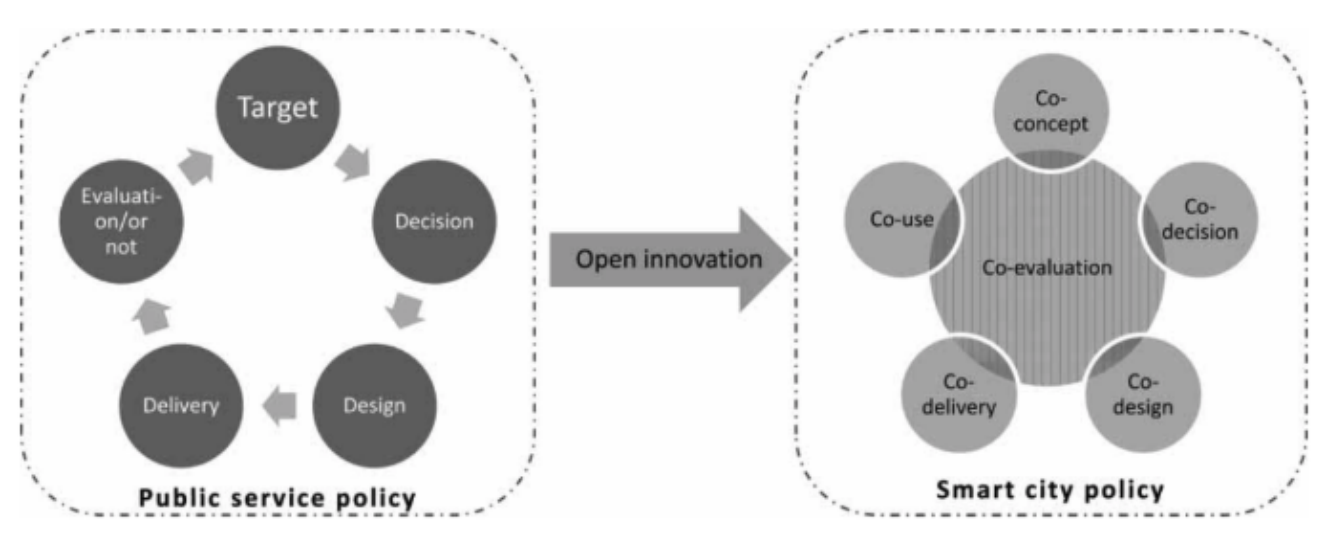

Figure 3. The transition of urban service development towards a sustainable open innovation model. (Source: Paskaleva, 2011) 


\section{Living Labs}

Living labs, which are gaining popularity worldwide, are both a milieu and methodology for actors such as the private sector, citizens, governments, and universities, to co-produce and test innovation in real life contexts (Bergvall-Kåreborn et al., 2009; Leminen, Westerlund \& Nyström, 2012). Living labs produce the practice-based knowledge that is critical to continuing innovation (Concilio \& Rizzo, 2016). Living labs are one way cities can implement open innovation. Despite good intentions, Living Labs have been criticized for not involving citizens in setting the initial policy direction that ultimately determines service priorities (Paskaleva, 2011).

\section{Innovation Stages}

Desouza et al. in 2009 outlined the stages of the innovation process. These stages are applicable to both open and closed innovation and are useful for understanding the steps along a city's path to smartness. The first stage is Idea Generation and Mobilization. New ideas are formed from scratch or are transferred from a different domain. Sometimes ideas respond to a pre-identified need, but not always. The next stage is Advocacy and Screening, or the evaluation of ideas. Screening weeds out ideas with a low probability of success and/or high cost of implementation. Advocacy for ideas is required to overcome the inertia of the status quo. The third stage is Experimentation. This is iterative prototyping to test an idea's applicability to a context or problem. Once an idea makes it past this stage, it is time for Commercialization. Commercialization means understanding the potential impact of an idea and creating marketing value from it. This typically requires refining the scope (which users, which contexts, which problems, which benefits). The final stage is Diffusion and Implementation. It is necessary to generate buy-in and acceptance of the new idea and then work to eliminate older, duplicative processes. 
Much attention is paid to involving citizens in early stages of innovation: Idea Generation and Mobilization and Advocacy and Screening. Crowdsourcing generates ideas from a large, unidentified group of individuals (the "crowd"), who respond voluntarily to an open call (EstellésArolas, 2012). As far as Advocacy and Screening goes, Schuurman et al. (2012) demonstrated that citizens are quite capable of selecting ideas with high user benefit and they do not require a large incentive to participate in this process online. Citizens are less frequently asked to be involved in later stages of the innovation process, though there is still a potential role. Civic hacking, the act using a city's open data to create new ways of delivering useful services to citizens, could involve members of the public in all five stages (Johnson \& Robinson, 2014). The later stages could involve members of the public as beta testers or community champions of the new idea. Viewing citizens as co-producers throughout all innovation stages is consistent with the upper rungs on the Ladder of Citizen Participation because it requires a transfer of power to members of the public (Arnstein, 1969).

\section{Citizen Participation in the Smart City}

As smart city paradigms take over cities, Cardullo \& Kitchin (2018) decided to revisit Arnstein's Ladder of Citizen Participation and modify it to fit with current contexts. Their most significant change was the addition of a ninth rung: choice. In neoliberal smart cities, city services and infrastructures are increasingly privatized and marketed (Cardullo \& Kitchin, 2018). This has caused a shift in the notion of citizenship away from civic responsibilities and engagements, toward classifying citizens as consumers (Cowley et al., 2018). The choice rung was slotted in between non-participation and tokenism because "consumerism in the smart city is 'citizencentric' in as far as it seeks to provide a selection of information and services from a range of entities that fulfil a need" (Cardullo \& Kitchin, 2018). Cardullo \& Kitchen also add a number of 
columns to Arnstein's ladder: role, citizen involvement, political discourse/framing, modality, and Dublin examples. Figure 4 depicts their Scaffold of Smart Citizen Participation.

\begin{tabular}{|c|c|c|c|c|c|c|}
\hline \multicolumn{2}{|c|}{$\begin{array}{l}\text { Form and Level of } \\
\text { Participation }\end{array}$} & Role & $\begin{array}{c}\text { Citizen } \\
\text { Involvement }\end{array}$ & $\begin{array}{c}\text { Political } \\
\text { discourse/ } \\
\text { framing } \\
\end{array}$ & Modality & Dublin Examples \\
\hline \multirow{3}{*}{ Citizen Power } & Citizen Control & $\begin{array}{l}\text { Leader, } \\
\text { Member }\end{array}$ & \multirow{2}{*}{$\begin{array}{c}\text { Ideas, Vision, } \\
\text { Leadership, } \\
\text { Ownership, } \\
\text { Create }\end{array}$} & \multirow{2}{*}{$\begin{array}{l}\text { Rights, } \\
\text { Social/Political } \\
\text { Citizenship, } \\
\text { Commons }\end{array}$} & \multirow{3}{*}{$\begin{array}{l}\text { Inclusive, } \\
\text { Bottom-up, } \\
\text { Collective, } \\
\text { Autonomy, } \\
\text { Experimental }\end{array}$} & $\begin{array}{c}\text { Code for Ireland, } \\
\text { Tog }\end{array}$ \\
\hline & $\begin{array}{l}\text { Delegated } \\
\text { Power }\end{array}$ & $\begin{array}{l}\text { Decision-maker, } \\
\text { Maker }\end{array}$ & & & & Civic Hacking, \\
\hline & Partnership & Co-creator & \begin{tabular}{|c|}
$\begin{array}{c}\text { Negotiate, } \\
\text { Produce }\end{array}$ \\
\end{tabular} & \multirow[b]{2}{*}{$\begin{array}{l}\text { Participation, } \\
\text { Co-creation }\end{array}$} & & $\begin{array}{l}\text { Hackathons, Living } \\
\text { Labs, Dublin Beta }\end{array}$ \\
\hline \multirow{3}{*}{ Tokenism } & Placation & Proposer & Suggest & & \multirow{7}{*}{$\begin{array}{l}\text { Top-down, } \\
\text { Civic } \\
\text { Paternalism, } \\
\text { Stewardship, } \\
\text { Bound-to- } \\
\text { succeed }\end{array}$} & $\begin{array}{l}\text { Fix-Your-Street, } \\
\text { Smart Dublin } \\
\text { Advisory Network }\end{array}$ \\
\hline & Consultation & $\begin{array}{l}\text { Participant, } \\
\text { Tester, } \\
\text { Player }\end{array}$ & Feedback & \multirow[t]{2}{*}{ Civic Engagement } & & $\begin{array}{l}\text { CIVIQ, Smart } \\
\text { Stadium }\end{array}$ \\
\hline & Information & Recipient & \multirow{3}{*}{$\begin{array}{l}\text { Browse, } \\
\text { Consume, } \\
\text { Act }\end{array}$} & & & $\begin{array}{l}\text { Dublinked, Dublin } \\
\text { Dashboard, RTPI }\end{array}$ \\
\hline \multirow{2}{*}{ Consumerism } & \multirow[t]{2}{*}{ Choice } & \multirow{2}{*}{$\begin{array}{l}\text { Resident, } \\
\text { Consumer }\end{array}$} & & \multirow{2}{*}{$\begin{array}{l}\text { Capitalism, } \\
\text { Market }\end{array}$} & & $\begin{array}{l}\text { Smart building/ } \\
\text { Smart district }\end{array}$ \\
\hline & & & & & & $\begin{array}{l}\text { Smart meters, } \\
\text { Mobile/locative } \\
\text { media }\end{array}$ \\
\hline \multirow{2}{*}{$\begin{array}{c}\text { Non- } \\
\text { Participation }\end{array}$} & Therapy & \multirow{2}{*}{$\begin{array}{c}\text { Patient, Learner, } \\
\text { User, Product, } \\
\text { Data-point }\end{array}$} & \multirow{2}{*}{$\begin{array}{l}\text { Steered, } \\
\text { Nudged, } \\
\text { Controlled }\end{array}$} & \multirow{2}{*}{$\begin{array}{l}\text { Stewardship, } \\
\text { Technocracy, } \\
\text { Paternalism }\end{array}$} & & $\begin{array}{l}\text { Dublin Bikes, } \\
\text { Smart Dublin }\end{array}$ \\
\hline & Manipulation & & & & & Traffic control \\
\hline
\end{tabular}

Figure 4. Scaffold of smart citizen participation. (Source: Cardullo \& Kitchin, 2018)

\section{Smart Governance}

Smart city innovations affect every aspect of urban development, including governance.

Municipal government has experienced technological transformation before. In the 1990s, the internet provided new ways to deliver services and be responsive to constituent needs (Guenduez et al., 2018). E-government replaced analog civic processes with digital equivalents, but it did not catalyze any large-scale changes in the structures or functions of public administration (Guenduez et al., 2018). Alone, ICTs do not deliver on promises of "empowering” and "democratizing" impacts (Paskaleva, 2011). Smart government uses ICTs, but also Big Data, IoT, and Artificial Intelligence (AI) to "passively and actively interact and collaborate with citizens so as to better 
understand their needs and to creatively, effectively, and efficiently provide services at any time (even predictively) and anywhere" (Guenduez et al., 2018, p. 97). Smart government supports participatory governance by increasing citizens' opportunities for direct deliberative engagement, through web 2.0, the geoweb, hackathons, and urban computation (Paskaleva, 2011; Guenduez et al., 2018; Sieber et al., 2016; Johnson \& Robinson, 2014; Salim \& Haque, 2015). Governments are eager to engage with citizens in this way, with $88.7 \%$ of smart city strategy documents examined by Tang et al. (2018) including a smart/digital government project.

Governments must evolve to keep up with the smart city and to meet the needs and expectations of citizens. There are many reasons why smart governance is needed. Trust in government continues to decline (Edelman, 2017). The transparency and open data inherent in smart government should help improve this sentiment, if these initiatives are framed in the context of democratic value rather than increasing efficiency (Cowley et al., 2018). Smart governance is also needed to build social cohesion in communities. Democratic participation can help citizens develop social networks, communication skills, and a sense of empowerment (Fischer, 2012). Capacity building (improving the community's ability to deal collectively with the problems it faces) can foster social cohesion (Fischer, 2012).

Inclusivity is a prime concern for smart governance. The digital divide is well-observed in the literature. Differences in access to internet and technology exist based on geography, gender, age, and socioeconomic status (Van Dijk, 2006; Cooper, 2006; Sieber et al., 2016). Sieber and colleagues (2016) suggest the concept of digital inequality (which includes the second and third generation digital divides) more accurately captures the dynamics within Canadian cities. The term includes but extends beyond "access" and considers how certain individuals may not be able to fully use a technology if they do not have the necessary technological skills, do not have a support network of technological peers, or lack control over their application usage (Sieber et al., 
2016; Hargittai, 2002). If this is the case, these are the issues smart governments must address to ensure equity in civic processes.

Beyond the imperative of digital inclusivity, as discussed above, analysis by Guenduez et al. (2018) discovered institutional, organizational, and leadership/strategy smart governance success factors. Institutional factors are system-level factors and include things like making a political commitment and allocating the appropriate resources, as well as building digital awareness among all smart city stakeholders. Organizational factors are internal to the municipal government, for example developing organizational capacity in fields such as data management, cyber security, and user experience design. Leadership/strategy factors relate to establishing a shared vision and understanding, rooting a smart governance strategy within the overall strategy, and having strong, cross-departmental leaders who act as champions. In addition to these factors, technological sovereignty (citizens' capacity to have a say and participate in how the technological infrastructure around them operates and what ends it serves) is suggested by Morozov \& Bria (2018) as a critical prerequisite for a democratic smart city agenda. This value should be embedded within the smart governance structure.

\section{Connecting the Literature to the Present Study}

This chapter has briefly described the existing body of literature related to public engagement for smart city initiatives. The smart city concept relies on innovation. Innovation is transformative, demanding the involvement of the public based on a belief that those who will be impacted by a decision have a right to be involved in the decision-making process. Smart cities can leverage their human capital by implementing open innovation processes and involving various actors including citizens, private sector, government, and academic institutions. Smart city innovations affect every aspect of urban development, including governance. Smart governance 
promises stronger links between citizens and government and new ways to participate, feeding back into the cycle of innovation.

The present study will contribute an empirical analysis of public engagement around smart city initiatives in Canada. The features of actually-occurring public engagement will be described and the theme of citizen involvement in the open innovation process will be further developed. The study's methodology is described in detail in the following chapter. 


\section{Chapter 3: Method}

The purpose of this study is to understand the extent to which the SCC catalyzed public engagement and describe how Canadian municipalities are engaging their residents around smart city initiatives. A review of the literature on public participation in smart city initiatives highlighted the importance of considering citizen involvement in the open innovation process. Therefore, this methodology will characterize the engagement processes described in SCC applications based on Desouza et al.'s (2009) stages of the innovation process. Other basic characteristics of the engagement processes employed by municipalities will also be tracked.

Applications were not analyzed if they were not available online at the time of collection, had problems with the electronic file, or were French language. As they were finalists and therefore important to include in the analysis, the applications from Montreal and Quebec City were translated to English using Google Translate, then coded and analyzed.

\section{Coding the Applications}

Only responses to Question 5 from the SCC Applicant Guide was analyzed for the present study (see Box 1). The coder read the Challenge Statement for context prior to reading and coding the municipality's full response to Question 5. Only information explicit in the response was considered. The coder's previous knowledge about the activities, links to external websites or additional information sources, and details about public engagement included elsewhere in the application were excluded during analysis for the purpose of consistency between applications. The coder kept coding memorandums, which facilitated the creation of a codebook (Appendix B) containing detailed definitions and instructions for coding. The codebook allows for replicability in the study. 


\section{Box 1. Question 5 from the SCC Applicant Guide.}

Please describe how your community residents have shaped your Challenge Statement. Describe your plans for continuing to engage and involve them in your final proposal going forward. $(1,500$ words $\max )$

This section should include:

- Descriptions of previous engagement with residents, businesses, organizations, and other stakeholders on topics related to the Challenge Statement.

- Descriptions of feedback that came to light through past engagement processes.

- Links between the Challenge Statement and engagement feedback.

- Evidence of efforts made to be inclusive and to represent the community's diversity.

- Plans to sustain engagement through the development and implementation of the final proposal.

It is important to note that the present study did not evaluate the applications according to the criteria laid out by Infrastructure Canada. That was a task most appropriate for, and already completed by, the SCC jury. Examining the submissions gives an idea of Canadian municipalities' current approach to public engagement and their awareness of and response to key issues related to smart city initiatives (e.g. digital inequality). In the finalist phase, the successful municipalities will receive education from experts on these issues and will be guided through thinking about them in a systematic way.

Applications were analyzed and coded based on the following questions:

1. Was the application selected as a finalist in the Smart Cities Challenge? Yes, No

2. Is there evidence that citizens helped to identify or define the community's most pressing issues? Yes, No

3. Did municipalities create opportunities for direct involvement of private citizens, their representatives, both, or neither?

4. Did municipalities leverage previously-conducted public engagement, conduct new engagement, both, or neither? 
5. Which engagement methods/activities did municipalities use? Online Survey, Public Meeting, Contest, Focus Group, Social Media, Written Submissions, Interviews, Citizen Advisory Role, Hackathon, etc.

6. Were engagement activities online, in-person, or both?

7. Was diversity and inclusion reflected in the design of public engagement? Yes, No

8. Was an explicit effort made to reduce digital inequality during public engagement? Yes, No

9. Was the public asked to contribute geospatial information? Yes, No

10. Which stages of the innovation process (Desouza et al., 2009) involved (or are proposed to involve) the public? Idea Generation and Mobilization, Advocacy and Screening, Experimentation, Commercialization, Diffusion and Implementation

The codes for most variables are a priori, meaning the categories were established based on previous literature or frameworks. The codes for question 10 were developed using grounded theory, where the categories come from the data itself. In all cases, the threshold for a code meant there was convincing evidence (in the coder's opinion) in the application to support the presence of the category.

For Questions 5 and 10, engagement completed up to the time of the application and engagement proposed for the next phase of the SCC were distinguished. For all other questions, excluding question 1 , only engagement completed up to the time of the application was considered since communities' abilities to carry out the proposed engagement is largely dependent on advancing as a finalist and the aim of the research was to comment on the impact of the SCC in furthering the public discourse on the smart city concept. 


\section{Analysis}

For the purpose of revealing overall trends in the data, frequency tables were prepared for each of the variables. Finalists and non-finalists were distinguished in the frequency tables, though the scope of the present study did not involve testing the statistical significance of any differences. 


\section{Chapter 4: Problem Investigation/Evidence and Findings}

\section{Overview}

Infrastructure Canada received 130 eligible applications for the first cycle of the SCC. This chapter describes the results of the analysis of 102 of these applications, including all 20 finalist applications and 82 non-finalist applications. Table 2 shows the breakdown of the applications that were analyzed in the present research. This analysis provides a snapshot of the public engagement that occurred across Canada in support of the SCC.

Table 2. Smart Cities Challenge applications analyzed.

\begin{tabular}{|l|l|l|}
\hline & All Applications & Analyzed \\
\hline Total & 130 & $102^{*}$ \\
\hline Finalists & 20 & 20 \\
\hline Non-finalists & 110 & 82 \\
\hline
\end{tabular}

\section{Describing the Engagement ${ }^{3}$}

\section{Identification of the Most Pressing Issues}

The SCC Applicant Guide instructs each municipality to "begin the Smart Cities Challenge process by engaging with residents about the most pressing issues their community faces” (Government of Canada, 2017). Community-identified pressing issues combine with data and

\footnotetext{
${ }^{3}$ From this point onwards, only analyzed applications $(n=102)$ are discussed. Please note that percentages may not total $100 \%$ due to rounding.
} 
evidence to determine the Challenge Statement (Government of Canada, 2018b). For the most part, this was accomplished. Table 3 shows that citizens helped to identify or define the most pressing issues in $87.2 \%$ of applications. All finalist municipalities developed proposals around issues citizens felt were important.

Table 3. Citizen involvement in identifying or defining the community's most pressing issues.

\begin{tabular}{|l|l|l|}
\hline & $\begin{array}{l}\text { Citizens helped identify/define } \\
\text { most pressing issues }\end{array}$ & $\begin{array}{l}\text { Citizens did not help } \\
\text { identify/define most pressing } \\
\text { issues }\end{array}$ \\
\hline Total & $89(87.2 \%)$ & $13(12.7 \%)$ \\
\hline Finalists & $20(100.0 \%)$ & $0(0.0 \%)$ \\
\hline Non-finalists & $69(84.1 \%)$ & $13(15.8 \%)$ \\
\hline
\end{tabular}

Some of the $12.7 \%$ of applications where citizens did not help identify or define the most pressing issues were submitted by municipalities that did not complete any public engagement. If there was no touchpoint with the public, the most pressing issues would have been identified by actors other than citizens. The direction of the application may have been set by a technology partner, the members of the core team, or other stakeholders. This is problematic because it opens the door for applications to primarily serve stakeholder or private sector interests instead of the public interest.

The remainder of the applications where citizens did not help identify or define the most pressing issues were coded as such because there was a lack of detail or clarity in their responses to Question 5. For example, the Township of Langley, British Columbia and the Kwantien First Nation organized a large marketing campaign involving posters, social media, a press release, and a digital billboard which aimed to inform citizens about the SCC and drive them to the campaign website to submit their ideas. They also hosted a number of internal brainstorming sessions with 
staff from the two communities and strategic partners. When reporting how the engagement informed their Challenge Statement, they collated feedback from the public and from staff and reported it together. Therefore, it was impossible to distinguish the extent (if any) to which citizens helped identify the most pressing issues in the community. This methodology is not ideal because it could be used to hide a low response rate from the public or deflect attention from the public's priorities to issues that staff find simpler to deal with or would benefit from personally. It calls into question the representativeness of the feedback and the overall direction of the Challenge Statement.

Another application, from the Mississaugas of the New Credit First Nation, indicated that their Challenge Statement was informed by their community's strategic plan. The formulation of the strategic plan in 2017 involved public engagement, but neither this public engagement nor the content of the strategic plan was described in their response to Question 5. The response focused on why a strategic plan is needed but did not adequately address the topics required by Infrastructure Canada for Question 5. There was insufficient information to conclude that citizens helped to identify the most pressing issues in their community. In a competition such as the SCC, a range in the quality of applications is to be expected, as municipalities have different staff capacity and expertise. There will also be cases where applicants misinterpret questions or instructions. Considering the vast majority of applications accomplished the requirement to engage citizens about the most pressing issues in their community and incorporated their feedback into the Challenge Statement, applications such as these should be deemed as one-offs.

A handful of applications demonstrate tension between popular issues and the most pressing issues. Especially in a socially-polarized city, the popular issues may not be the most urgent or best solved through a smart city approach. Issues that disproportionately affect marginalized populations may not receive broad public support. This could be due to a lack of 
awareness or discrimination. The City Toronto corrected for this bias by employing an advisory group of citizens who took the time to learn about the various issues, examine data, review feedback from the broader public, and make a final informed recommendation. This approach resulted in the selection of the issue of vulnerable residents in older high-rise apartment neighbourhoods.

There is a lingering question about at which point in the SCC (if at all), municipalities have an obligation to check in with the public about the proposed technology solutions to address the pressing issues. The application process outlined in the Applicant Guide directs municipal staff (potentially with expert help) to develop the ideas and activities that will make up their preliminary Smart Cities Challenge proposal, with no requirement of public consultation at this time (Government of Canada, 2017, p. 6-7). The assumption implicit within these instructions to municipalities is that citizens will support any technology solution that addresses the most pressing issue they identified. With this assumption, technological sovereignty is not afforded to Canadians (Morozov \& Bria, 2018).

Looking at a smart city project unrelated to the SCC, we find evidence that Canadians do care about the details of how smart city initiatives are designed and implemented. Sidewalk Labs' Quayside project in Toronto makes promises such as: "Housing and real estate that is more efficient and thus far more affordable", "A mobility system that is safer and more convenient than the private car at much lower cost", and "A new standard of sustainability" (Sidewalk Labs, 2019). These promises align with needs identified by Torontonians during City-run community consultations (for example, City of Toronto, 2009; City of Toronto \& Toronto Atmospheric Fund, 2016; City of Toronto, 2018). Despite this, the Quayside project has experienced consistent criticism from citizens concerned about privacy and Sidewalk Labs' business model, culminating in the formation of a citizen-led campaign called \#BlockSidewalk (BlockSidewalk, n.d.). The 
campaign calls to reset and reimagine the project with a more democratic process and co-design with citizens (Bliss, 2019). To summarize learnings from Quayside, citizens may support the proposed outcomes of a smart city initiative but may vehemently oppose a specific technology solution to achieve those outcomes. Implementation of smart city initiatives will have a lasting impact on citizens, so they want a role in designing exactly how technology solutions will roll out.

This research has demonstrated that the vast majority of municipalities engaged their communities to learn about the most pressing issues they face. However, it was observed that few municipalities reported back on the technology solutions they later developed to address those needs. Citizens were typically not provided an opportunity to ask questions, express concerns, or show support for technology solutions prior to the submission of their community's SCC application. For finalists, this ground-truthing may come in the next phase of public engagement. But is this too late? If non-finalist municipalities decide to advance their smart city initiatives with alternate sources of funding, will this important public consultation occur, or will they forge ahead with false confidence their citizens back their initiatives? The SCC could encourage public discussions about outcomes and technology solutions to be treated independently to avoid conflation.

\section{Opportunities for Direct Involvement of Citizens}

Table 4 reveals approximately three quarters of municipalities engaged directly with citizens (direct democracy), in addition to engaging with their formal (i.e. elected officials) and informal (e.g. residents' associations, non-profit service providers, etc.) representatives (representative democracy). $11.8 \%$ of municipalities developed their SCC applications based exclusively on direct engagement with private citizens and $9.8 \%$ of municipalities did not engage private citizens directly, relying on representatives to provide insight to the needs of the 
community. There was little difference between finalists and non-finalists, indicating that the choice whether to directly engage citizens or their representatives did not impact the quality of the application from the perspective of the SCC jury.

Table 4. Types of democracy built into the public engagement process.

\begin{tabular}{|l|l|l|l|l|}
\hline & $\begin{array}{l}\text { Direct } \\
\text { democracy }\end{array}$ & $\begin{array}{l}\text { Representative } \\
\text { democracy }\end{array}$ & Both & Neither \\
\hline Total & $12(11.8 \%)$ & $10(9.8 \%)$ & $78(76.5 \%)$ & $2(2.0 \%)$ \\
\hline Finalists & $2(10.0 \%)$ & $3(15.0 \%)$ & $15(75.0 \%)$ & $0(0.0 \%)$ \\
\hline Non-finalists & $10(12.2 \%)$ & $7(8.5 \%)$ & $63(76.8 \%)$ & $2(2.4 \%)$ \\
\hline
\end{tabular}

The City of Airdrie, a finalist in the competition used an effective combination of direct and representative democracy to develop their Challenge Statement. The City first identified health as a pressing issue through their annual resident satisfaction survey (direct democracy). Then, they selected citizen representatives from the community based on health needs (e.g. maternal and infant, chronic conditions, end-of-life, etc.). They also selected representatives from the spectrum of organizations with an interest in the project (e.g. physicians, seniors' organizations, faith communities, school systems, etc.). They engaged the citizen and organization representatives through focus groups (representative democracy). Airdrie proposed a smart city initiative about connecting technologies to enable the flow of data and content to inform a community approach to health. In the next phase of engagement, the City anticipates continuing the needs-based groups and matching citizen representatives with the organizations that serve them. The City of Airdrie's public engagement provided an opportunity for the community-atlarge to direct the overall focus on the project. Upon the selection of health as the as the focus, Airdrie switched to representative democracy. This was appropriate because health is a universal issue and directly engaging such a large group would be logistically and financially prohibitive. 
Selecting representatives eased that burden and also purposely sought out the perspectives of people facing health challenges, whose views might otherwise be overlooked due to difficulties participating.

Direct democracy (where private citizens contribute directly to political decisions) and representative democracy (where representatives participate in political decisions on their constituents' behalf) each serve a purpose. Direct democracy is important for understanding unique lived experiences and builds buy-in from members of the community. In the SCC, direct democracy is well-suited to investigating the community's most pressing issues. Representative democracy is resource efficient and prevents engagement fatigue among the general public, saving their time and energy for when it really counts. Representative democracy is effective where decisions are complex or technical and the average citizen may struggle to grasp the full extent of the issues and the short- and long-term impacts of the decision. Smart city initiatives may or may not fall into this category. More investigation is required to understand if certain technical elements of smart city initiatives are beyond comprehension for public audiences and are better suited to decisions made through representative democracy. Research suggests that the public, including marginalized groups, can rise to this challenge as long as adequate education and supports are provided (Fischer, 2012). If that is the case, Infrastructure Canada and municipalities need to think about how to provide education and supports.

\section{Making Use of New and Previously-Conducted Engagement}

Municipalities were encouraged to leverage any recent and relevant public engagement in the development of their applications. In Table 5 you will see a total of $79.4 \%$ of municipalities did that. Most of those municipalities supplemented leveraged engagement with new engagement. $17.6 \%$ of municipalities only completed new engagement without considering the results of 
previously-conducted engagement. The percent of finalists who utilized both previous and new engagement $(70 \%)$ was substantially higher than non-finalists $(53.7 \%)$.

Table 5. New and previously-conducted engagements.

\begin{tabular}{|l|l|l|l|l|}
\hline & New engagement & $\begin{array}{l}\text { Leveraged } \\
\text { previous } \\
\text { engagement }\end{array}$ & Both & $\begin{array}{l}\text { Neither/Unknow } \\
\mathrm{n}\end{array}$ \\
\hline Total & $18(17.6 \%)$ & $23(22.5 \%)$ & $58(56.9 \%)$ & $2(2.0 \%)$ \\
\hline Finalists & $4(20.0 \%)$ & $1(5.0 \%)$ & $14(70.0 \%)$ & $1(5.0 \%)$ \\
\hline Non-finalists & $14(17.1 \%)$ & $22(26.8 \%)$ & $44(53.7 \%)$ & $1(1.2 \%)$ \\
\hline
\end{tabular}

Previous engagement that was commonly leveraged for SCC applications included Citizen Satisfaction Surveys and engagement from the most recent formation or review of municipalitylevel plans (e.g. official plans in Ontario or official community plans in British Columbia). In municipalities where smart city conversations are just beginning, it is important to remember that the context of those previous engagements may have been very different. Citizens were likely not fully aware of all the benefits and risks of a smart city approach. They may have identified pressing issues in their community, but not provided express consent for technology-driven solutions. They may have had a different solution in mind, such as increased service levels or a new policy.

Some municipalities who leaned more heavily on leveraging previous engagement mentioned being wary of engagement fatigue amongst their populations. This is a critical discussion, especially for a competition that may not result in any funding for projects. The SCC should consider how to encourage meaningful engagement while respecting citizens' time and energy. Participation in the SCC should not compromise municipalities' ability to collect highquality feedback from citizens for their other future projects. 


\section{Engagement Activities}

A variety of engagement activities took place across the country, as evidenced by Table 6 . Engagement activities were sorted into 23 categories (definitions of these categories are available in the codebook in Appendix B).

Figure 5. Top 5 Engagement Activities Completed by all Applicants.

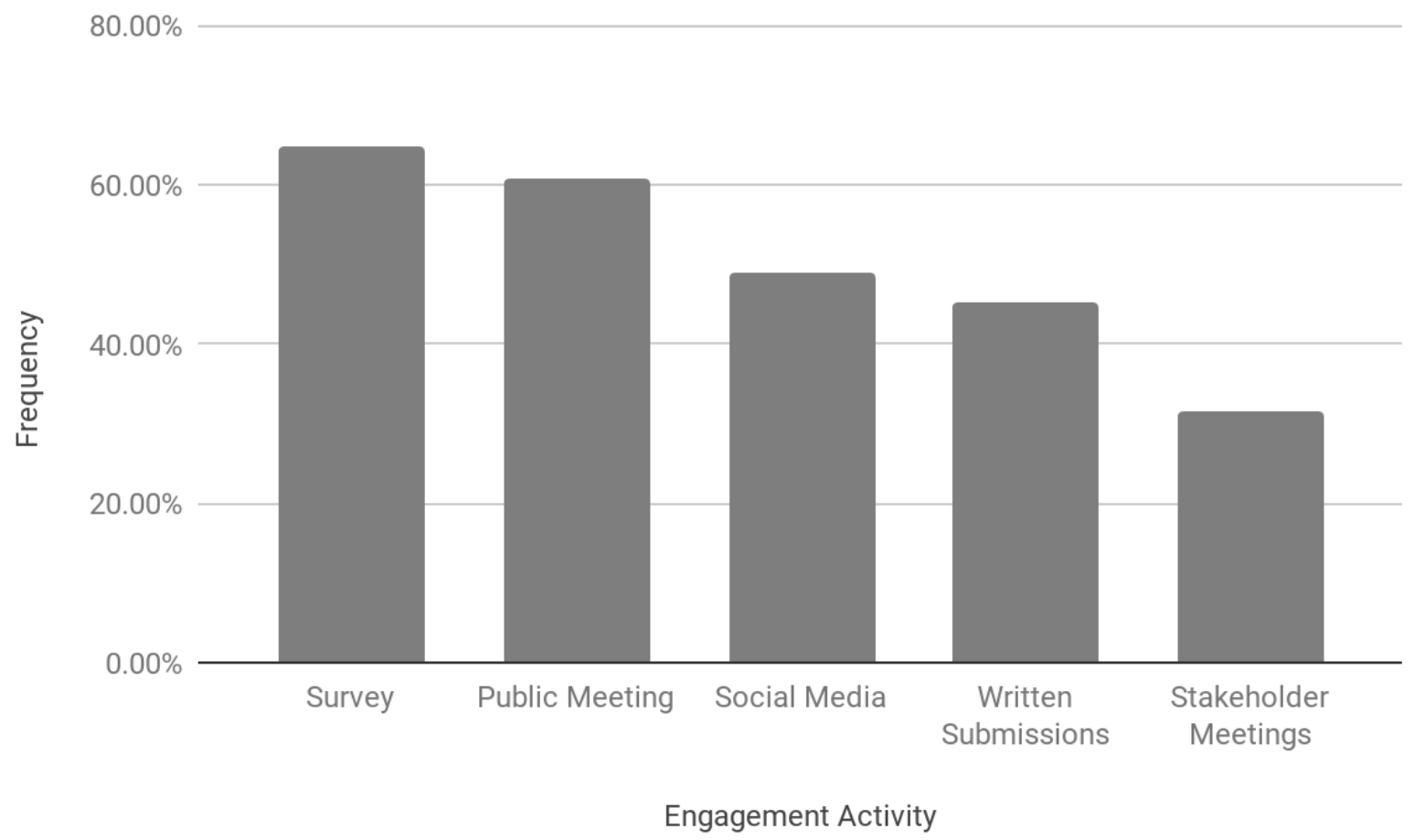

Figure 5 presents the engagement activities that occurred most frequently in the applicant phase of the SCC. Surveys and public meetings were most popular, with $64.7 \%$ and $60.8 \%$ of municipalities employing these tactics, respectively. In this phase, municipalities seemed to favour a few "tried and true" engagement activities. The incorporation of some of these activities (e.g. public meetings) in planning legislation may also explain their frequency of use. These activities would therefore have been common in applications from municipalities that leveraged previous 
engagement. In addition, previous experience with these techniques might make them simpler to implement for municipalities.

Figure 6. Top 5 Engagement Activities Proposed by Finalists.

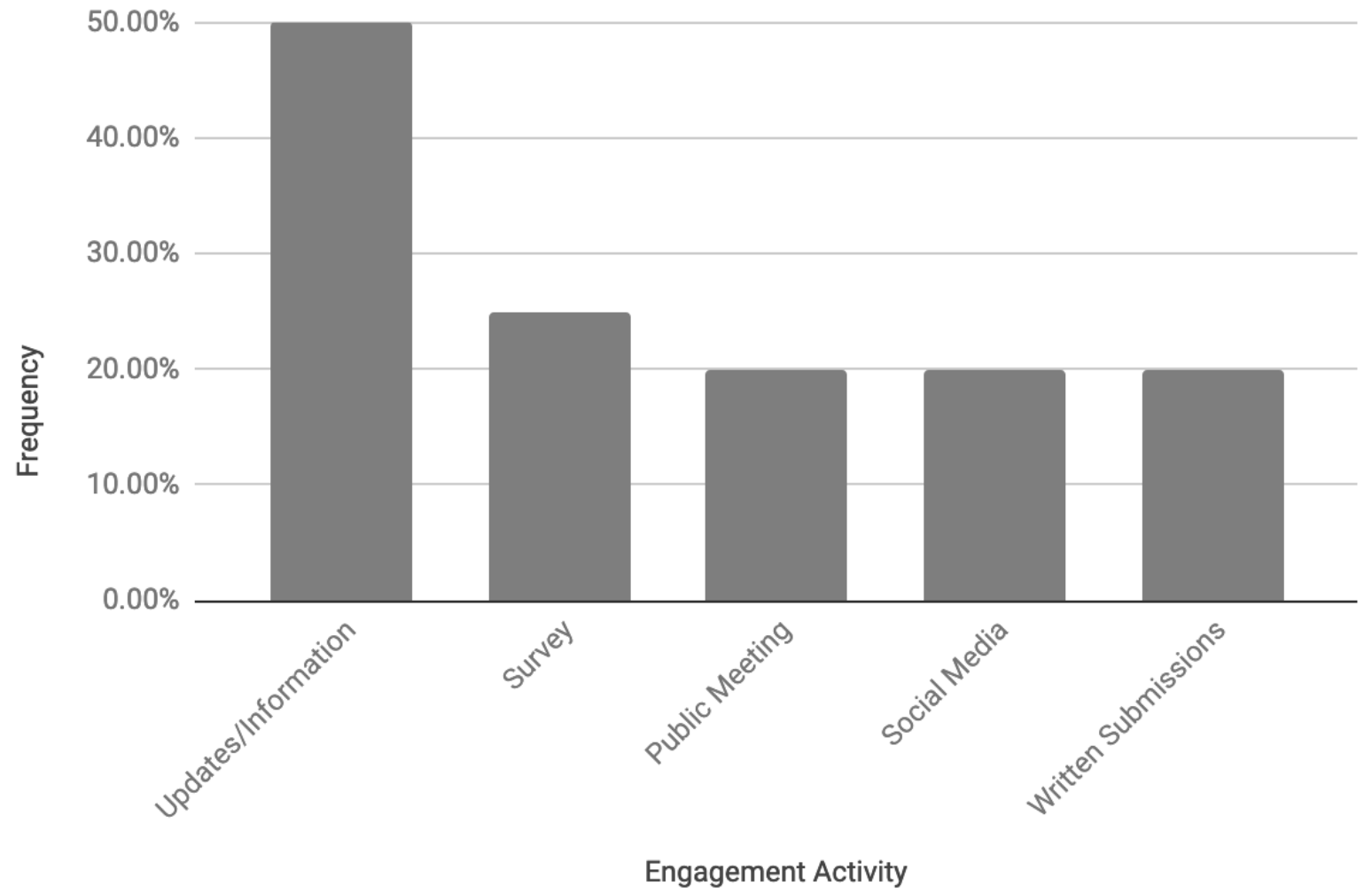

The most frequently proposed activities by finalist municipalities for the second phase of the SCC and the implementation phase are shown in Figure 6. Many of the activities that were popular in the first phase of the SCC are repeated here, though with reduced frequencies. Updates/Information were described as a planned engagement activity by half the finalist municipalities - the most frequent activity by a large margin. "Informing" is low on the Ladder of Citizen Participation, which is a cause for concern if this engagement activity supplants others that might offer a higher degree of citizen power (Arnstein, 1969). Infrastructure Canada may wish to monitor this in the finalist phase. Although it is important to report back to citizens on the 
municipality's success in the Challenge and next steps, used alone Updates and Information do not constitute meaningful public engagement.

Table 6. Engagement activities.

\begin{tabular}{|l|l|l|l|l|l|l|}
\hline & \multicolumn{2}{|l|}{ Total } & \multicolumn{2}{l|}{} & \multicolumn{2}{l}{ Non-Finalists } \\
\hline & $\begin{array}{l}\text { Completed } \\
\text { in } \\
\text { Applicant } \\
\text { Phase }\end{array}$ & $\begin{array}{l}\text { Proposed } \\
\text { for Finalist } \\
\text { Phase }\end{array}$ & $\begin{array}{l}\text { Completed } \\
\text { in } \\
\text { Applicant } \\
\text { Phase }\end{array}$ & $\begin{array}{l}\text { Proposed } \\
\text { for Finalist } \\
\text { Phase }\end{array}$ & $\begin{array}{l}\text { Completed } \\
\text { in } \\
\text { Applicant } \\
\text { Phase }\end{array}$ & $\begin{array}{l}\text { Proposed } \\
\text { for Finalist } \\
\text { Phase }\end{array}$ \\
\hline Survey & $66(64.7 \%)$ & $16(15.7 \%)$ & $12(60.0 \%)$ & $5(25.0 \%)$ & $54(65.9 \%)$ & $11(13.4 \%)$ \\
\hline $\begin{array}{l}\text { Public } \\
\text { Meeting }\end{array}$ & $62(60.8 \%)$ & $24(23.5 \%)$ & $8(40.0 \%)$ & $4(20.0 \%)$ & $54(65.9 \%)$ & $20(24.4 \%)$ \\
\hline $\begin{array}{l}\text { Focus } \\
\text { Group }\end{array}$ & $23(22.5 \%)$ & $10(9.8 \%)$ & $6(30.0 \%)$ & $1(5.0 \%)$ & $17(20.7 \%)$ & $9(11.0 \%)$ \\
\hline $\begin{array}{l}\text { Social } \\
\text { Media }\end{array}$ & $50(49.0 \%)$ & $18(17.6 \%)$ & $6(30.0 \%)$ & $4(20.0 \%)$ & $44(53.7 \%)$ & $14(17.1 \%)$ \\
\hline $\begin{array}{l}\text { Written } \\
\text { Submission }\end{array}$ & $46(45.1 \%)$ & $20(19.6 \%)$ & $8(40.0 \%)$ & $4(20.0 \%)$ & $38(46.3 \%)$ & $16(19.5 \%)$ \\
\hline Contest & $5(4.9 \%)$ & $1(1.0 \%)$ & $1(5.0 \%)$ & $1(5.0 \%)$ & $4(4.9 \%)$ & $0(0.0 \%)$ \\
\hline $\begin{array}{l}\text { Citizen } \\
\text { Advisory }\end{array}$ & $21(20.6 \%)$ & $16(15.7 \%)$ & $3(15.0 \%)$ & $2(10.0 \%)$ & $18(22.0 \%)$ & $14(17.1 \%)$ \\
\hline Interviews & $22(21.6 \%)$ & $8(7.8 \%)$ & $8(40.0 \%)$ & $3(15.0 \%)$ & $14(17.1 \%)$ & $5(6.1 \%)$ \\
\hline Hackathon & $10(9.8 \%)$ & $3(2.9 \%)$ & $4(20.0 \%)$ & $1(5.0 \%)$ & $6(7.3 \%)$ & $2(2.4 \%)$ \\
\hline Workshop & $30(29.4 \%)$ & $16(15.7 \%)$ & $8(40.0 \%)$ & $2(10.0 \%)$ & $22(26.8 \%)$ & $14(17.1 \%)$ \\
\hline $\begin{array}{l}\text { Citizen Rep } \\
\text { on Core } \\
\text { Team }\end{array}$ & $10(9.8 \%)$ & $9(8.8 \%)$ & $2(10.0 \%)$ & $1(5.0 \%)$ & $8(9.8 \%)$ & $8(9.8 \%)$ \\
\hline $\begin{array}{l}\text { Planners in } \\
\text { Public } \\
\text { Spaces }\end{array}$ & $21(20.6 \%)$ & $6(5.9 \%)$ & $1(5.0 \%)$ & $1(5.0 \%)$ & $20(24.4 \%)$ & $5(6.1 \%)$ \\
\hline Citizen & $6(5.9 \%)$ & $5(4.9 \%)$ & $5(25.0 \%)$ & $2(10.0 \%)$ & $1(1.2 \%)$ & $3(3,7 \%)$ \\
\hline
\end{tabular}




\begin{tabular}{|l|l|l|l|l|l|l|}
\hline Panel & & & & & \\
\hline $\begin{array}{l}\text { Updates/Inf } \\
\text { ormation }\end{array}$ & $18(17.6 \%)$ & $33(32.4 \%)$ & $4(20.0 \%)$ & $10(50.0 \%)$ & $14(17.1 \%)$ & $23(28.0 \%)$ \\
\hline Meeting & $32(31.4 \%)$ & $15(14.7 \%)$ & $4(20.0 \%)$ & $3(15.0 \%)$ & $28(34.1)$ & $12(14.6 \%)$ \\
\hline $\begin{array}{l}\text { Host } \\
\text { Conference }\end{array}$ & $13(12.7 \%)$ & $4(3.9 \%)$ & $2(10.0 \%)$ & $0(0.0 \%)$ & $11(13.4 \%)$ & $4(4.9 \%)$ \\
\hline $\begin{array}{l}\text { Classroom } \\
\text { Activities }\end{array}$ & $2(2.0 \%)$ & $1(1.0 \%)$ & $1(5.0 \%)$ & $1(5.0 \%)$ & $1(1.2 \%)$ & $0(0.0 \%)$ \\
\hline $\begin{array}{l}\text { Call-in } \\
\text { Radio } \\
\text { Show }\end{array}$ & $2(2.0 \%)$ & $0(0.0 \%)$ & $0(0.0 \%)$ & $0(0.0 \%)$ & $2(2.4 \%)$ & $0(0.0 \%)$ \\
\hline $\begin{array}{l}\text { Art/Tactical } \\
\text { Urbanism }\end{array}$ & $2(2.0 \%)$ & $3(2.9 \%)$ & $0(0.0 \%)$ & $0(0.0 \%)$ & $2(2.4 \%)$ & $3(3.7 \%)$ \\
\hline $\begin{array}{l}\text { Kiosks } \\
\text { Engagemen } \\
\text { t Activities }\end{array}$ & $0(0.0 \%)$ & $1(1.0 \%)$ & $0(0.0 \%)$ & $0(0.0 \%)$ & $0(0.0 \%)$ & $1(1.2 \%)$ \\
\hline $\begin{array}{l}\text { Tour } \\
\text { Placement }\end{array}$ & $1(1.0 \%)$ & $1(1.0 \%)$ & $0(0.0 \%)$ & $0(0.0 \%)$ & $1(1.2 \%)$ & $1(1.2 \%)$ \\
\hline $\begin{array}{l}\text { Gamificatio } \\
\mathrm{n}\end{array}$ & $0(0.0 \%)$ & $1(1.0 \%)$ & $0(0.0 \%)$ & $0(0.0 \%)$ & $0(0.0 \%)$ & $1(1.2 \%)$ \\
\hline $\begin{array}{l}\text { Internship/ } \\
\text { No Public }\end{array}$ & $0(0.0 \%)$ & $1(1.0 \%)$ & $0(0.0 \%)$ & $0(0.0 \%)$ & $0(0.0 \%)$ & $1(1.2 \%)$ \\
\hline
\end{tabular}

Six applications $(5.9 \%)$ - five from non-finalists and one from a finalist - contained no convincing evidence that any public engagement activities were completed prior to participation in the SCC. This could point to a lack of capacity, time or expertise from the municipalities. A few municipalities noted that they became aware of the SCC late and did not have sufficient time to engage. The six applications were all from smaller municipalities with populations under 100,000. The one finalist application that was coded as having completed no engagement activities was from the Nunavut Association of Municipalities. The application did reference engaging certain 
representatives from the communities (i.e. Community Liaison Officers, Economic Development Officers, and Community Wellness Officers) but did not describe specific activities undertaken. The size of this applicant group (24 Nunavut communities in total) and the word limit for Question 5 may have discouraged detailed accounts of each community's engagement activities.

Twenty-seven applications $(26.5 \%)$ did not propose specific activities for future public engagement, if they were to be selected as a finalist. These municipalities promised they would develop a public engagement plan in the next phase but lacked detail in their applications. The proportion of municipalities that did not precisely describe their ongoing engagement were similar for finalists and non-finalists. I hypothesize that certain finalists used the majority of the word limit for Question 5 to describe their completed engagement activities, which earned them a high score with the SCC jury but left little room to discuss their future plans for involving the public. The finalist phase of the SCC requires fully developed engagement plans.

Finalists and non-finalists engaged differently for the SCC. Surveys were the dominant engagement activity for both groups. However, finalists completed more interviews, workshops, hackathons, and citizen panels than non-finalists. Non-finalists leaned more heavily on public meetings, "planners in public spaces", and social media than finalists. Some of the more unique and innovative ideas for public engagement came from non-finalists (see Box 2). Municipalities may have struggled to communicate the value or outcomes of more unusual engagement activities to the SCC jury.

\section{Box 2. Unique Engagement Ideas from Non-Finalists.}

Internships/Work Placements City of Kingston, Ontario

- The City ran the Mayor's Innovation Challenge, a pitch competition for students and recent grads which resulted in four-month paid internships at the City and the DuninDeshpande Queen's Innovation Centre. Winners used the internship (and seed funding) 
to further develop their innovations with mentorship from municipal and academic leaders.

Empathy Mapping via Sentiment Analysis

City of Kingston, Ontario

- The City used data mining and sentiment analysis to create empathy maps (user personas used in design thinking process) and capture the underlying causes of "pain points" identified by the community and stakeholders.

Travelling Signs with Social Media Campaign

City of Penticton, British Columbia

- The \#10forPenticton campaign involved the construction of several three-foot tall, bright blue number " 10 "s that travelled around to places where the community gathers. Volunteers had conversations with citizens, recorded feedback, and encouraged selfies with the 10 s to keep the conversation going online.

Call-in Radio Show

City of Windsor-Essex, Ontario

- The City used a popular local radio show to facilitate a public discussion about issues in the community and technology- and data-driven solutions. Residents could call in and share their feedback and ideas live on the air.

Tactical Urbanism \& Art

Clarence-Rockland, Ontario; City of Calgary, Alberta; City of Mississauga, Ontario

- These municipalities used or proposed art or tactical urbanism to spark conversations. Artworks or tactical urbanism projects act as sources of triangulation, encouraging strangers to strike up conversations. This informal discussion and debate play an important civic role: it helps form consensus among community members, promotes tolerance and understanding of different views, and builds social cohesion.

Citizen Working Groups and the "Reverse Pitch"

Moncton, New Brunswick

- For the next round of public engagement, Moncton proposed assigning specific challenges to working groups of citizens and post-secondary students. They would brainstorm and pitch their ideas to private sector sponsors, who would be responsible for gathering the complete solutions according to the direction from the working group.

Vox Pop

Bromont, Quebec

- Vox Pop is a journalism technique of short interviews on the street with members of the public about a topical political issue. The interviews are video recorded and compiled into a segment that is meant to represent popular opinion.

Pop-up Shop

Abbotsford, British Columbia

- A pop-up shop in a vacant storefront at the local shopping centre helped planners share preliminary concepts and collect questionnaires from over 700 citizens. 


\section{Venues for Public Engagement: Online vs. In-person}

As shown in Table 7, when preparing their SCC applications, most municipalities $(74.5 \%)$ engaged the public both online and in-person. Online surveys were frequently paired with inperson engagement activities such as public meetings or workshops. Only Richmond, British Columbia engaged exclusively online. There were 19 municipalities that only held in-person engagement activities, which is an interesting choice given that this is a competition related to data and connected technology. No rationale was provided for this choice, but it is worthwhile to note that all of these municipalities had populations under 500,000 and 10 had populations under 30,000. There are several reasons why small municipalities might prefer in-person engagement to online engagement:

- Municipal staff may not have access to appropriate technology to conduct online engagement;

- Residents may not have accessible and reliable internet connection, making online engagement unlikely to be successful; and

- Small municipalities may foster a tight-knit and engaged community that is willing to come out in high numbers to in-person engagement activities, making online engagement obsolete.

Table 7. Venue for public engagement.

\begin{tabular}{|l|l|l|l|l|}
\hline & Online & In-person & Both & Neither \\
\hline Total & $1(1.0 \%)$ & $19(18.6 \%)$ & $76(74.5 \%)$ & $4(3.9 \%)$ \\
\hline Finalists & $1(5.0 \%)$ & $3(15.0 \%)$ & $15(75.0 \%)$ & $0(0.0 \%)$ \\
\hline Non-finalists & $0(0.0 \%)$ & $16(19.5 \%)$ & $61(74.4 \%)$ & $4(4.9 \%)$ \\
\hline
\end{tabular}




\section{Diversity and Inclusion}

Question 5 required applicants to describe their efforts to be inclusive and how they captured the diversity of the community. However, barely half of the municipalities presented convincing evidence that diversity and inclusion were reflected in the design of their public engagement (see Table 8). A misunderstanding that was apparent among municipalities is that "wide promotion" of engagement activities is sufficient to ensure the participation of a representative sample of community members. This logic ignores the fact that certain communities face barriers to participation beyond awareness, such as lack of childcare, mobility challenges, and distrust of government, among others (Kart \& Kinney, 2001; Montesanti et al., 2016). Facilitating participation of seldom heard groups therefore requires additional supports tailored to the specific community.

Table 8. Diversity and inclusion reflected in the design of public engagement.

\begin{tabular}{|l|l|l|}
\hline & $\begin{array}{l}\text { Diversity and inclusion } \\
\text { reflected in design }\end{array}$ & $\begin{array}{l}\text { Diversity and inclusion not } \\
\text { reflected in design }\end{array}$ \\
\hline Total & $57(55.9 \%)$ & $45(44.1 \%)$ \\
\hline Finalists & $12(60.0 \%)$ & $8(40.0 \%)$ \\
\hline Non-finalists & $45(54.9 \%)$ & $37(45.1 \%)$ \\
\hline
\end{tabular}

\section{Digital Inequality}

Very few municipalities mentioned undertaking initiatives aimed at reducing digital inequality during their public engagement activities. Percentages are shown in Table 9. Digital inequality is a concern during public engagement in the SCC for two reasons:

1. A lack of digital literacy limits the ability for citizens to provide informed feedback on smart city initiatives. 
2. Three-quarters of municipalities ran online engagements. Those without reliable internet connection, technology, or digital literacy would have been excluded from these activities.

Table 9. Reducing digital inequality.

\begin{tabular}{|l|l|l|}
\hline & $\begin{array}{l}\text { Explicit effort made to reduce } \\
\text { “digital inequality" }\end{array}$ & $\begin{array}{l}\text { No explicit effort made to } \\
\text { reduce "digital inequality" }\end{array}$ \\
\hline Total & $15(14.7 \%)$ & $87(85.3 \%)$ \\
\hline Finalists & $6(30.0 \%)$ & $14(70.0 \%)$ \\
\hline Non-finalists & $9(11.0 \%)$ & $73(89.0 \%)$ \\
\hline
\end{tabular}

The municipalities that did address digital inequality during public engagement $(14.7 \%)$, did so mostly in the form of education to help residents increase their understanding of the concept of smart cities. There were no examples of personal assistance for those with lower levels of digital literacy, nor any programs aimed at increasing the public's access to technology. This finding highlights the risk of digital stratification in Canadian municipalities that move forward with their smart city proposals, with a growing difference between citizens who can access and benefit from data and connected technology and those who are left behind.

\section{Collecting Geospatial Data}

Table 10 reveals that less than $3 \%$ of municipalities asked their citizens to contribute geospatial data, for example to identify area-specific issues. However, collection of geospatial data is featured prominently in the technology and data solutions proposed by many municipalities. It begs the question of why place-based solutions are being applied to problems defined without geospatial basis.

This finding may suggest that Canadian municipalities eager to become "smart" assume that digital connectivity will replace the need for physical connectivity in cities. Certain theoretical 
literature supports this view (see Dear, 1995), while other authors disagree (for example, see Mitchell, 1999; Walters, 2011; Florida, 2002). These critics argue that "in a society that enables us to live and work anywhere we like, the places we choose to inhabit become more precious and important" (Walters, 2011, p. 202). The smartest places are therefore those that offer the best of both worlds; the spaces that are assigned meaning through digital and physical interventions (Mitchell, 1999). I tend to side with the critics, and do not think it is wise to abandon careful consideration of place when building smart cities.

Table 10. Collecting geospatial data.

\begin{tabular}{|l|l|l|}
\hline & $\begin{array}{l}\text { Public contributed geospatial } \\
\text { data }\end{array}$ & $\begin{array}{l}\text { Public did not contribute } \\
\text { geospatial data }\end{array}$ \\
\hline Total & $3(2.9 \%)$ & $98(96.1 \%)$ \\
\hline Finalists & $0(0.0 \%)$ & $20(100.0 \%)$ \\
\hline Non-finalists & $3(3.7 \%)$ & $79(96.3 \%)$ \\
\hline
\end{tabular}

There are methods for collecting geospatial data that would have been appropriate for use by municipalities in the SCC. For example, geo-questionnaire is a method of collecting public input through map sketching/marking and by answering questions triggered by map interactions (Czepkiewicz et al., 2017). Alternatively, argumentation maps (Rinner, 2001), geo-discussions (Leahy \& Hall, 2010) allow for citizens to interact with each other and debate geospatial data. Through these methods, it is possible to measure spatial attributes such as patterns of behaviour, values and valuable places, experiences and subjective evaluations, and development preferences (Czepkiewicz et al., 2017). Citizens are variably motivated to partake in these methods and submit geospatial information. Some common motivators include a sense of altruism, pride of place, or a sentiment that data ought to be free (Sieber et al., 2016). 


\section{Open Innovation Stages}

The majority of Canadian municipalities are not involving (nor planning to involve) residents in the open innovation process beyond Idea Generation and Mobilization, as established by Table 11. There is a marked lack of attention to the role of citizens in Experimentation, Commercialization, and Diffusion and Implementation.

The choice to involve the public is the result of at least the following three factors:

1. Understanding of how to involve the public at that innovation stage;

2. Recognizing the value of involving citizens (benefit vs. cost); and

3. Willingness to transfer some power to citizens (i.e. move to a higher rung on the Ladder of Citizen Participation).

Most municipalities that participated in the SCC are in a preliminary period of their smart city programs. They may not have progressed beyond the first two stages yet. So, whether the public is being purposefully excluded based on the aforementioned factors or simply due to a lack of a long-term strategy (and therefore difficulty in articulating their future plans) remains to be seen. This should be monitored as the SCC continues.

Collectively, finalists included the public in the open innovation process to a much greater extent than non-finalists. The majority of the finalists presented plans to involve citizens in at least the first three stages. This finding could suggest that:

- municipalities who have taken great care to design a smart city initiative are likely to recognize the value of public participation in the innovation process and understand how to involve them, and/or 
- the SCC jury favoured applications that were built on open innovation ecosystems with citizen involvement.

Table 11. Citizen involvement in the five stages of open innovation.

\begin{tabular}{|c|c|c|c|c|c|c|c|c|c|c|}
\hline & \multicolumn{2}{|c|}{$\begin{array}{l}\text { Idea } \\
\text { Generation and } \\
\text { Mobilization }\end{array}$} & \multicolumn{2}{|c|}{$\begin{array}{l}\text { Advocacy and } \\
\text { Screening }\end{array}$} & \multicolumn{2}{|c|}{$\begin{array}{l}\text { Experimentatio } \\
n\end{array}$} & \multicolumn{2}{|c|}{$\begin{array}{l}\text { Commercializa } \\
\text { tion }\end{array}$} & \multicolumn{2}{|c|}{$\begin{array}{l}\text { Diffusion and } \\
\text { Implementatio } \\
\text { n }\end{array}$} \\
\hline & $\begin{array}{l}\text { Compl } \\
\text { eted in } \\
\text { Applic } \\
\text { ant } \\
\text { Phase }\end{array}$ & $\begin{array}{l}\text { Propo } \\
\text { sed for } \\
\text { Finalis } \\
\mathrm{t} \\
\text { Phase }\end{array}$ & $\begin{array}{l}\text { Compl } \\
\text { eted in } \\
\text { Applic } \\
\text { ant } \\
\text { Phase }\end{array}$ & $\begin{array}{l}\text { Propo } \\
\text { sed for } \\
\text { Finalis } \\
t \\
\text { Phase }\end{array}$ & $\begin{array}{l}\text { Compl } \\
\text { eted in } \\
\text { Applic } \\
\text { ant } \\
\text { Phase }\end{array}$ & $\begin{array}{l}\text { Propo } \\
\text { sed for } \\
\text { Finalis } \\
\mathrm{t} \\
\text { Phase }\end{array}$ & $\begin{array}{l}\text { Compl } \\
\text { eted in } \\
\text { Applic } \\
\text { ant } \\
\text { Phase }\end{array}$ & $\begin{array}{l}\text { Propo } \\
\text { sed for } \\
\text { Finalis } \\
\mathrm{t} \\
\text { Phase }\end{array}$ & $\begin{array}{l}\text { Compl } \\
\text { eted in } \\
\text { Applic } \\
\text { ant } \\
\text { Phase }\end{array}$ & $\begin{array}{l}\text { Propo } \\
\text { sed for } \\
\text { Finalis } \\
\mathrm{t} \\
\text { Phase }\end{array}$ \\
\hline Total & 58 & 33 & 38 & 21 & 8 & 26 & 1 & 9 & 1 & 10 \\
\hline$\%$ & $56.9 \%$ & $32.4 \%$ & $37.3 \%$ & $20.6 \%$ & $7.8 \%$ & $25.5 \%$ & $1.0 \%$ & $8.8 \%$ & $1.0 \%$ & $9.8 \%$ \\
\hline $\begin{array}{l}\text { Finalis } \\
\text { ts }\end{array}$ & 15 & 13 & 16 & 19 & 3 & 12 & 1 & 8 & 1 & 5 \\
\hline$\%$ & $75.0 \%$ & $65.0 \%$ & $80.0 \%$ & $95.0 \%$ & $15.0 \%$ & $60.0 \%$ & $5.0 \%$ & $40.0 \%$ & $5.0 \%$ & $25.0 \%$ \\
\hline $\begin{array}{l}\text { Non- } \\
\text { finalist } \\
\mathrm{s}\end{array}$ & 43 & 20 & 22 & 2 & 5 & 14 & 0 & 1 & 0 & 3 \\
\hline$\%$ & $52.4 \%$ & $24.4 \%$ & $26.8 \%$ & $2.4 \%$ & $6.1 \%$ & $17.1 \%$ & $0.0 \%$ & $1.2 \%$ & $0.0 \%$ & $6.1 \%$ \\
\hline
\end{tabular}

\section{Summary of Findings}

The results previously described in this chapter were obtained through coding and analyzing 102 SCC applications. These results provide insight into how Canadian municipalities are engaging the public in smart city initiatives. In general, Canadian municipalities are:

- offering participation opportunities directly to citizens, in addition to their representatives;

- leveraging previously-conducted public engagement and supplementing it with new 
engagement specific to smart cities;

- engaging the public most often via surveys, public meetings, social media, written submissions, and stakeholder meetings, both online and in-person;

- too often not making an explicit effort engage seldom heard groups;

- not working to reduce digital inequality throughout the public engagement process;

- choosing not to collect or use geospatial data; and

- not involving citizens fully in the open innovation process.

The findings also highlight some key differences between municipalities that were successful in the SCC (advancing to the finalist phase) and those who were unsuccessful. Notably, compared to non-finalists, finalist municipalities more frequently conducted new public engagement specifically related to the SCC, made efforts to reduce digital inequality during public engagement, and involved citizens in all five stages of the open innovation process. Therefore, these are the characteristics of engagement that were deemed desirable by the SCC jury. 


\section{Chapter 5: Conclusion and Recommendations for Practice and Future Research}

The purpose of this research is for Canadian municipalities to learn from their collective experiences engaging the public in smart city initiatives and do better. The first cycle of the SCC has highlighted some key areas to address in future smart cities work. In the sections that follow, recommendations are provided for Infrastructure Canada and municipal planners. Directions for future research are discussed and the limitations of this work are addressed.

\section{Conclusions}

This research aimed to describe the public engagement resulting from Infrastructure Canada's first Smart Cities Challenge. 102 of 130 eligible applications submitted by Canadian municipalities were coded and analyzed; narrowing in on municipalities' descriptions of their completed public engagement and what they had planned for the future if they were selected as

finalists in the SCC. The analysis considered engagement methods and activities, efforts to include diverse populations and reduce barriers to participate, and the extent of public involvement in defining the issue and co-producing innovative solutions. This method provided a snapshot of how Canadian municipalities engaged their citizens during the development and implementation of a smart city initiative.

The analysis revealed that Canadian municipalities met the SCC requirement to engage their communities on their most pressing issues. Municipalities employed a broad range of activities (including some highly creative techniques) as well as leveraged previously-conducted engagement. They consulted with citizens directly and with their formal and informal 
representatives. $86 \%$ of the municipalities supported their citizens to identify and define their community's most pressing issue, which became the focus for their Challenge Statement. There was opportunity for improvement in municipalities' efforts to engage seldom heard groups. Although they widely promoted their engagements to combat lack of awareness, they did not go far enough to remove or reduce the other barriers to participation certain populations face.

Where Canadian municipalities struggled was helping the public navigate the additional complexity a smart city approach brings. There was a widely-held assumption that citizens will support any technology solution that solves their pressing problems. Because of this assumption, municipalities did not provide sufficient access to information to allow for a public discourse about the benefits and risks of various technology solutions. Municipalities also demonstrated uncertainty about how to address digital inequality and how to connect place with the smart city framework. Analysis of public involvement in the five stages of open innovation showed that coproduction stalls in the later stages. Municipalities are typically not involving the public at all in the Commercialization or Diffusion and Implementation stages. A significant amount of the difficulty encountered by municipalities can be attributed to the fact that many of them are attempting a smart city approach for the first time. There is much to be learned from their early experiences. The recommendations that follow will provide some direction for improvement.

\section{Recommendations}

\section{Recommendations for Infrastructure Canada}

\section{Recommendation 1: Revise instructions to municipalities and application questions related to public engagement.}


The SCC Applicant Guide should spell out exactly what is expected of applicants in terms of public engagement. Based upon the pattern of selection of finalists, the Challenge expects the following:

- The process of selecting the community's most pressing issues will be citizen-led;

- Municipalities will make an effort to reduce digital inequality during engagement activities and the project as a whole;

- Municipalities will conduct new public engagement specific to the topic of smart cities in support of their applications; and

- The innovation ecosystem will include citizens from Idea Generation and Mobilization through to Diffusion and Implementation (all five stages).

The SCC should require applicants to consult citizens twice during the competition: first to determine the most pressing issues, then again when developing the proposed technology-driven solution. Infrastructure Canada should consider the timing of these two consultations and whether both should occur before the initial application. There is a requirement for finalists to "maintain the essence of their challenge statements and outcomes" in their full proposal (Government of Canada, 2018b). Does this preclude a course correction if finalists learn that their communities are unhappy with the technology solution proposed to address their pressing issues? Possibly not, but clarification is required. All communities should have a digital right to their city, including sufficient information to provide informed consent and the power to shape details of the proposal they do not support. Municipalities must be explicitly instructed of this because the risks with undemocratic smart cities are great.

\section{Recommendation 2: Provide education and resources to municipalities on public engagement for smart city initiatives.}


This research has identified areas where the knowledge within municipalities may be inadequate to produce high-quality public engagement. There is a clear need to help municipalities understand how to include citizens in each stage of the open innovation process and the value of doing so. The result should be an increase in citizen involvement in open innovation ecosystems. As well, education on equity, diversity, and inclusion would equip municipalities to empathize and address the real barriers to participation faced by certain populations.

There are resources developed by other organizations that could be easily made available to SCC applicants. For example, Bang the Table (self-described as "a digital community engagement company with a strong social mission") has produced a free eBook titled Public Engagement with the Smart City (Hussey, 2018). This resource summarizes research from international academics and consultants about topics including e-participation, digital right to the city, data privacy and ownership concerns, and what happens when citizens are excluded from smart city initiatives. It should be required reading for every municipality considering a smart city approach. Another valuable resource to share is Making a Civic Smart City, created through a collaboration between the Engagement Lab at Emerson College, the City as Platform Lab at the University of Waterloo, and the Center for Smart Cities and Regions at Arizona State University. This resource consists of a Workshop (agenda, printable materials) and a Play Book (discussions and action ideas). Used together, cities can "define their own localized version of 'smart', and to construct a workable strategy to encourage greater engagement with publics in the civic processes of designing the smart city” (Gordon et al., 2018).

Having the Smart Cities Community Support Program compile these resources and share it is a better use of public funds than each municipality reproducing the same. This would be especially beneficial to small municipalities that may lack the capacity to complete this detailed research in house. 


\section{Recommendation 3: Develop a new program to reduce digital inequality across Canada.}

Public engagement around smart city initiatives exists in a landscape of digital inequality. Empowering Canadians to influence how their communities evolve into smart cities requires computer and internet access and digital literacy skills. The present research demonstrates that Canadian municipalities have been unsuccessful at tackling digital inequality during their public engagement for the SCC. If the federal government is pushing a smart city agenda, then it has the obligation to ensure all Canadians benefit. In some cases, entire communities are being left behind. There are small, rural communities in Canada that lack broadband internet and opportunities for learning about technology. Without these basics, it is difficult for municipalities to develop compelling and feasible smart city plans that can meaningfully compete in the SCC. Uploading the burden of eliminating the digital divide to the federal government would be complementary to the SCC and would help level the playing field for future competitions.

\section{Recommendation 4: Create a "menu" of public engagement activities used in previous cycles of the SCC to inspire municipalities.}

Some municipalities relied on traditional methods of public engagement, such as public meetings or surveys. Others developed highly creative ways to engage their citizens. Overall, there were 23 different categories of engagement activities used by Canadian municipalities. Within each category there was additional variation as municipalities adapted methods to local contexts. A "menu" would provide a list of engagement activities with brief descriptions and notes relating to their execution. Creative public engagement can reduce engagement fatigue, attract higher levels of participation, and reach people who don't participate in traditional engagement activities like public meetings. A menu may spark more creative public engagement in future SCC competitions. 


\section{Recommendation 5: Sustain the Smart Cities Community Support Program.}

An obstacle for the SCC is how to respect the time and energy committed by citizens within a competition structure where not all municipalities will receive funding to put their plans into action. The Smart Cities Community Support Program is a vital support to all Canadian municipalities with an interest in the smart city approach, but especially for the unsuccessful SCC applicants who want to pursue smart city initiatives with alternate funding sources. This will help more municipalities implement smart city initiatives and ensure citizens' time and effort participating in consultation is not wasted.

It is my recommendation that the funding provided to Evergreen and Open North for the Community Solutions Network be extended from to five years, which is the expected timeframe for implementation of winners' smart city initiatives, as noted within the SCC Finalist Guide (Government of Canada, 2018b). Unsuccessful SCC applicants may implement their initiatives over a longer period of time according to availability of funding. Municipalities need to know the supports offered by the Community Solutions Network will be available over the longer-term so they may plan implementation appropriately. After 5 years (a full cycle of the SCC) the Community Support Program should be evaluated and then reconsidered for additional, stable, long-term funding.

\section{Recommendations for Municipal Planners}

\section{Recommendation 6: Remain vigilant about the public interest.}

Smart city initiatives present new challenges to public-private partnerships. The significant involvement of private sector firms in SCC applications requires vigilance to ensure public interests, not private interests, guide smart city projects. A democratic process for the development 
of smart cities requires that the public be engaged before the private sector. Citizens should agree to a smart city approach and set the terms for what they want (Wylie, 2019). Citizens and government should establish a regulatory framework together that protects public interests (Wylie, 2019). Only then should procurement for a technology vendor begin. This means that public engagement must be run by governments, not the private sector (Wylie, 2019). By separating the engagement and procurement processes it ensures the public interest rather than private interests guide the design of the project. Complexity arises in municipalities where the economy is dominated by a single industry. In this case, public and private interests may be largely aligned, but it is important to also be aware of the powerful influence of a large employer on a population with few other economic opportunities.

\section{Recommendation 7: Use public engagement as an opportunity to reduce digital inequality.}

A mix of online and in-person engagement ensures that citizens with low digital literacy are not excluded from civic involvement. However, analog alternatives to digital engagements on their own do not build an individual's capacity for ongoing participation in the smart city. Education and training should be incorporated into public engagement. Planners should use public touchpoints to connect citizens with free or low-cost programs that can increase their access to internet, technology, and training. By reducing digital inequality, more citizens are able to reap the benefits of smart city initiatives. They are also better prepared to participate in online public engagement in the future.

\section{Recommendation 8: Don't forget about place.}

Humans can't live in the cloud; they will continue to experience life in the physical realm despite the addition of a digital layer to our cities. To maintain quality of life, it is essential that planners do not ignore place in conversations about smart cities. As territoriality is a strong 
motivator for public engagement, planners should consider using geospatial data in public engagements to drive participation (Paskaleva, 2011). Methods including geo-questionnaires, argumentation maps, and geo-discussions may be employed. Planners in Public Spaces, tactical urbanism and tours are engagement activities familiar to municipalities through the SCC which, if appropriately designed, could also be used to facilitate place-based smart city planning.

\section{Limitations of this Research}

This research has limitations. Most significantly, it relied on information provided by municipalities within their SCC applications. A 1500-word limit for Question 5 may have constrained how comprehensively engagement was described. Also, the language used to describe engagement varied between sectors, geographic locations, languages, and individuals, and in some cases lacked precision. For example, a common activity described was a "community engagement session”, which could refer to many types of engagement activities. A fair amount of inference was required to apply a consistent code to heterogeneous terminology, thus introducing the potential for error. The exclusion of French-language applications is problematic because it impacted one province in particular: Quebec. Fewer than half the applications from Quebec municipalities were analyzed in this study.

\section{Recommendations for Future Research}

Building off this study's finding that Canadian municipalities are not involving citizens in the full open innovation process, future research should be designed to develop an empirical understanding of successful citizen involvement in smart city innovation ecosystems. It should explore the best practices for open innovation in the smart city context. Future research should carefully examine the later stages of Commercialization and Diffusion and Implementation and 
confirm if citizen involvement is useful and appropriate here. If so, tested methods for involving citizens in these stages should be articulated.

The evidence base could also benefit from an improved understanding of Canadians’ actual level of knowledge of the smart city concept. Research could explore the following questions:

- What does the concept mean to them?

- Do they understand common terminology (IoT, AI, etc.)?

- Do they have positive or negative associations with the concept?

- Are they aware of both the benefits and risks of using data and connected technology?

- Does the level of knowledge differ based on age, level of education, location or other characteristics?

This research would illuminate for municipalities the level of education required for the public to provide informed feedback on smart city initiatives. It would also call attention to extent of digital inequality and the main populations impacted by low digital literacy.

Finally, I suggest that the SCC continue to be studied for lessons learned. Future research should seek to describe public engagement in the finalist and implementation phases of the SCC, as this study has done for the applicant phase. Exploring correlations between public engagement and measures of citizen support of or opposition to smart city initiatives may address the lingering question about if citizens support any technology solution that addresses their most pressing issues. Future research should also address if the SCC produced better engagement, more engagement, neither or both.

Although the present research makes a small contribution, serious knowledge gaps persist on the topic of public engagement for smart city initiatives. This is a fascinating field of study with 
critical need. If we want to create equitable, open, and democratic cities of the future, we need to better understand how to involve the public in discussions about cities and technology. I hope that researchers take up this call to action. 


\section{References}

Alawadhi, S., Aldama-Nalda, A., Chourabi, H., Gil-Garcia, J. R., Leung, S., Mellouli, S., ... \& Walker, S. (2012, September). Building understanding of smart city initiatives. In International conference on electronic government (pp. 40-53). Springer, Berlin, Heidelberg.

Appio, F. P., Lima, M., \& Paroutis, S. (2018). Understanding Smart Cities: Innovation ecosystems, technological advancements, and societal challenges. Technological Forecasting and Social Change.

Arnstein, S. R. (1969). A ladder of citizen participation. Journal of the American Institute of planners, 35(4), 216-224.

Bergvall-Kåreborn, B., Eriksson, C. I., Ståhlbröst, A., \& Svensson, J. (2009). A milieu for innovation: defining living labs. In ISPIM Innovation Symposium: 06/12/2009. 09/12/2009.

Bliss, L. (2019, February 25). Critics Vow to Block Sidewalk Labs' Controversial Smart City in Toronto. City Lab. Retrieved March 1, 2019, from https://www.citylab.com/equity/2019/02/block-sidewalk-labs-quayside-toronto-smart-cityresistance/583477/

BlockSidewalk. (n.d.). BlockSidewalk. Retrieved March 1, 2019, from https://www.blocksidewalk.ca/

Bloom, R., Lauriault, T. P., \& Landry, J. (2018, April). Open Smart Cities in Canada: Assessment Report (Rep.). Retrieved http://osf.io/QBYZJ

Brady, H. E., Verba, S., \& Schlozman, K. L. (1995). Beyond SES: A resource model of political participation. American Political Science Review, 89(2), 271-294.

Caragliu, A., Del Bo, C., \& Nijkamp, P. (2011). Smart cities in Europe. Journal of urban technology, 18(2), 65-82.

Cardullo, P., \& Kitchin, R. (2018). Being a 'citizen' in the smart city: up and down the scaffold of smart citizen participation in Dublin, Ireland. GeoJournal, 1-13.

Chesbrough, H. W. (2003). The era of open innovation. MIT Sloan Management Review, 44(3), 35 .

Chourabi, H., Nam, T., Walker, S., Gil-Garcia, J. R., Mellouli, S., Nahon, K., Pardo, T. \& Scholl, H. J. (2012, January). Understanding smart cities: An integrative framework. System Science (HICSS), 2012 45th Hawaii International Conference on System Sciences (pp. 2289-2297). IEEE. 
City of Toronto. Housing Opportunities Toronto. (2009). Retrieved from: https://www.toronto.ca/wp-content/uploads/2018/12/94f8-hot_actionplan.pdf

City of Toronto. TOcore Public Open House on the Proposed Downtown Plan and Associated Infrastructure Strategies - Summary Report. (2018). Retrieved from https://www.toronto.ca/wp-content/uploads/2018/01/94fe-city-planning-tocore-dec2-openhouse-summary-aoda.pdf

City of Toronto \& Toronto Atmospheric Fund. Talk Transformation: Buildings and Energy in a Low-Carbon Toronto. (2016). Retrieved from https://www.toronto.ca/wpcontent/uploads/2017/10/8fdf-TransformTO-Energy-Buildings-Workbook-SummaryAODA.pdf

Clement, A. (2018, January 12). Sidewalk Labs' Toronto waterfront tech hub must respect privacy, democracy. Retrieved from https://www.thestar.com/opinion/contributors/2018/01/12/sidewalk-labs-torontowaterfront-tech-hub-must-respect-privacy-democracy.html

Cocchia, A. (2014). Smart and digital city: A systematic literature review. Smart city (pp. 13-43). Springer, Cham.

Concilio, G., \& Rizzo, F. (Eds.). (2016). Human smart cities: rethinking the interplay between design and planning. Retrieved from https://ebookcentral-proquestcom.ezproxy.lib.ryerson.ca

Cooper, J. (2006). The digital divide: The special case of gender. Journal of Computer Assisted Learning, 22(5), 320-334.

Cowley, R., Joss, S., \& Dayot, Y. (2018). The smart city and its publics: insights from across six UK cities. Urban Research \& Practice, 11(1), 53-77.

Czepkiewicz, M., Jankowski, P., \& Zwoliński, Z. (2018). Geo-questionnaire: a spatially explicit method for eliciting public preferences, behavioural patterns, and local knowledge-an overview. Quaestiones Geographicae, 373), 177-190.

Dear, M. (1995). Prolegomena to a postmodern urbanism. Managing cities: the new urban context, 27-44.

Desouza, K. C., Dombrowski, C., Awazu, Y., Baloh, P., Papagari, S., Jha, S., \& Kim, J. Y. (2009). Crafting organizational innovation processes. Innovation, 11(1), 6-33.

Edelman, R. (2017). 2017 Edelman trust barometer: Global report.

Estellés-Arolas, E., \& González-Ladrón-De-Guevara, F. (2012). Towards an integrated crowdsourcing definition. Journal of Information science, 38(2), 189-200.

Evergreen. (2019). Community Solutions Network. Retrieved from https://futurecitiescanada.ca/programs-projects/learning-networks/community-solutionsnetwork/ 
Fischer, F. (2012). Participatory Governance: From Theory to Practice. Oxford Handbook of Governance. D. Levi-Faur (Ed.). Oxford: Oxford University Press, 457-71.

Florida, R. (2002). The rise of the creative class(Vol. 9). New York: Basic books.

Giffinger, R., Fertner, C., Kramar, H., \& Meijers, E. (2007). City-ranking of European mediumsized cities. Cent. Reg. Sci. Vienna UT, 1-12. Retrieved from http://www.smartcities.eu/download/smart_cities_final_report.pdf

Gordon, E., Coleman, B., Harlow, J., Teng, M., \& Meaning, L. (2018). Making a Civic Smart City: Designing for Public Value and Civic Participation(Rep. No. 05).

Government of Canada. (2017). Smart Cities Applicant Guide I Impact Canada. Retrieved from https://impact.canada.ca/en/challenges/smart-cities/applicant-guide

Government of Canada. (2018a). Smart Cities Community Support Program Application Submission Guide I Impact Canada. Retrieved from https://www.infrastructure.gc.ca/citiesvilles/support-guide-soutien-eng.html

Government of Canada. (2018b). Smart Cities Finalist Guide I Impact Canada. Retrieved from https://impact.canada.ca/en/challenges/smart-cities/finalist-guide

Grossi, G., \& Pianezzi, D. (2017). Smart cities: Utopia or neoliberal ideology?. Cities, 69, 79-85.

Guenduez, A. A., Singler, S., Tomczak, T., Schedler, K., \& Oberli, M. (2018). Smart Government success factors. Yearbook of Swiss Administrative Sciences, 9(1).

Hargittai, E. (2002). Second-level digital divide: Differences in people's online skills. First monday, 7(4).

Hollands, R. G. (2008). Will the real smart city please stand up? Intelligent, progressive or entrepreneurial?. City, 12(3), 303-320.

Hussey, S. (Ed.). (2018). Public Engagement with the Smart City. Retrieved from https://www.bangthetable.com/resources/public-engagement-smart-city/

IAP2 Canada. (2018). Core Values for the Practice of Public Participation. Retrieved from https://iap2canada.ca/corevalues

Johnson, P., \& Robinson, P. (2014). Civic hackathons: Innovation, procurement, or civic engagement?. Review of Policy Research, 31(4), 349-357.

Karpowitz, C. F., \& Raphael, C. (2016). Ideals of inclusion in deliberation. Journal of Public Deliberation, 12(2), 3.

Kart, C. S. \& Kinney, J. M. (2001). The realities of aging: An introduction to gerontology (6th ed.). Needham Heights, MA: Allyn and Bacon. 
Leahy M., Hall G.B., 2010. Using open source software components to implement a modular Web 2.0 design for map-based discussions. International Journal of Open Source Software and Processes 2(3): 30-47.

Lee, J. H., Hancock, M. G., \& Hu, M. C. (2014). Towards an effective framework for building smart cities: Lessons from Seoul and San Francisco. Technological Forecasting and Social Change, 89, 80-99.

Leminen, S., Westerlund, M., \& Nyström, A. G. (2012). Living Labs as open-innovation networks.

Mitchell, W. J. (1999). e-topia:" Urban life, Jim-but not as we know it". MIT press.

Montesanti, S. R., Abelson, J., Lavis, J. N., \& Dunn, J. R. (2016). Enabling the participation of marginalized populations: case studies from a health service organization in Ontario, Canada. Health promotion international, 32(4), 636-649.

Morozov, E., \& Bria, F. (2018). Rethinking the smart city. Democratizing Urban Technology. New York, NY: Rosa Luxemburg Foundation.

Nam, T., \& Pardo, T. A. (2011, September). Smart city as urban innovation: Focusing on management, policy, and context. In Proceedings of the 5th international conference on theory and practice of electronic governance (pp. 185-194). ACM.

Neirotti, P., De Marco, A., Cagliano, A. C., Mangano, G., \& Scorrano, F. (2014). Current trends in Smart City initiatives: Some stylised facts. Cities, 38, 25-36.

OECD/Eurostat (2018), Oslo Manual 2018: Guidelines for Collecting, Reporting and Using Data on Innovation, 4th Edition, The Measurement of Scientific, Technological and Innovation Activities, OECD Publishing, Paris/Eurostat, Luxembourg. https://doi.org/10.1787/9789264304604-en

Paskaleva, K. A. (2011). The smart city: A nexus for open innovation?. Intelligent Buildings International, 3(3), 153-171.

Pattie, C., Seyd, P. and Whiteley, P. (2003) 'Civic Attitudes and Engagement in Modern Britain', Parliamentary Affairs, 56, 616-633.

Rinner C., 2001. Argumentation maps: GIS-based discussion support for on-line planning. Environment and Planning B: Planning and Design 28(6): 847-863. DOI: 10.1068/b2748t.

Salim, F., \& Haque, U. (2015). Urban computing in the wild: A survey on large scale participation and citizen engagement with ubiquitous computing, cyber physical systems, and Internet of Things. International Journal of Human-Computer Studies, 81, 31-48.

Sauter, M. (2018, February 13). Google's Guinea-Pig City. Retrieved from

https://www.theatlantic.com/technology/archive/2018/02/googles-guinea-pig-city/552932/ 
Schuurman, D., Baccarne, B., De Marez, L., \& Mechant, P. (2012). Smart ideas for smart cities: investigating crowdsourcing for generating and selecting ideas for ICT innovation in a city context. Journal of theoretical and applied electronic commerce research, 73), 49-62.

Sidewalk Labs. (2019). Sidewalk Labs. Retrieved March 1, 2019, from https://www.sidewalklabs.com/

Sidewalk Toronto. (n.d.). Sidewalk Toronto. Retrieved from https://sidewalktoronto.ca/

Sieber, R. E., Robinson, P. J., Johnson, P. A., \& Corbett, J. M. (2016). Doing public participation on the geospatial web. Annals of the American Association of Geographers, 106(5), 10301046.

Tang, Z., Jayakar, K., Feng, X., Zhang, H., \& Peng, X. (2018). Conceptualizing implementation frameworks from the bottom up: A content analysis of smart city plans.

Thorson, J. A. (2000). Aging in a Changing Society (2nd ed.). Brunner/Mazel: Philadelphia.

Van Dijk, J. A. (2006). Digital divide research, achievements and shortcomings. Poetics, 34(4-5), 221-235.

Walters, D. (2011). Smart cities, smart places, smart democracy: Form-based codes, electronic governance and the role of place in making smart cities. Intelligent Buildings International, 3(3), 198-218.

Wylie, B. (2018). Open Data Endgame: Countering the Digital Consensus. Retrieved from https:/www.cigionline.org/sites/default/files/documents/Paper\%20no.186web.pdf

Wylie, B. (2019, February 19). Did the Sidewalk Labs plot just thicken, or is the story coming to an end? Spacing Toronto. Retrieved from http://spacing.ca/toronto/2019/02/19/did-thesidewalk-labs-plot-just-thicken-or-is-the-story-coming-to-an-end/

Zuboff, S. (2013). The Surveillance paradigm: Be the friction - Our Response to the New Lords of the Ring. Retrieved from http://www.faz.net/aktuell/feuilleton/the-surveillance-paradigmbe-the-friction-our-response-to-the-new-lords-of-the-ring-12241996.html 


\section{Appendices}

\section{Appendix A: List of Smart Cities Challenge Finalists and Prize Amounts}

\section{\$5 Million Prize Category}

- Biigtigong Nishnaabeg (Pic River First Nation), Ontario

- Cree Nation of Eastmain, Quebec

- Town of Bridgewater, Nova Scotia

- Mohawk Council of Akwesasne, Quebec

- City of Yellowknife, Northwest Territories

\$10 Million Prize Category

- Town of The Pas, Opaskwayak Cree Nation, Rural Municipality of Kelsey, Manitoba

- City of Côte Saint-Luc, Quebec

- Nunavut Communities, Nunavut

- Saint Mary's First Nation and City of Fredericton, New Brunswick

- Parkland, Brazeau, Lac Ste Anne and Yellowhead Counties, Alberta

- City of Airdrie and Area, Alberta

- City of Richmond, British Columbia

- City of Guelph \& Wellington County, Ontario

- City of Saskatoon, Saskatchewan

- Greater Victoria, British Columbia

\section{\$50 Million Prize Category}

- Region of Waterloo, Ontario

- Quebec City, Quebec

- City of Edmonton, Alberta

- City of Surrey \& City of Vancouver, BC

- Montréal, Quebec 


\section{Appendix B: Codebook}

\section{Overall Instructions}

- Read the Challenge Statement for context and the full response to Question 5.

- Any information contained in web links or references made to other sections of the application are not to be considered.

- The threshold for assigning a code is convincing evidence.

\section{Assumptions}

- Individuals participating in a consultation as a representative of a private sector firm are only acting in the best interest of the firm, not their personal interest as citizens.

- All activities could occur online or offline. For example, an in-person focus group or a focus group held via webinar technology. Surveys could be online or paper copies.

- Stakeholder engagement is only considered to be public engagement where stakeholders act in the interest of their communities. Typically, these stakeholders are non-profit organizations.

\section{Definitions}

Finalist: A municipality identified in Appendix A.

Non-finalist: Any municipality who participated in the SCC and does not meet the definition of a finalist.

Most pressing issues: This refers to issues considered by the public to be the most pressing, which may or may not be consistent with the most pressing issues identified by data or other means.

Direct democracy: Input from private citizens contributes to the development of the proposal.

Representative democracy: Representatives contribute on behalf of a larger group of citizens. Representatives may include elected officials, organizational representatives or informal community leaders.

Leveraging previously-conducted public engagement: The results of public engagement activities completed prior to the announcement of the SCC are re-examined in the context of a smart city approach and the SCC.

Conducting new public engagement: Engagement activities are designed and executed after the announcement of the SCC for the primary purpose of developing an application to the Challenge.

Survey: A questionnaire completed by members of the public.

Public meeting: Any large, public gathering, open to all members of the public, where information is shared, opportunity for member of the public to provide comments. 
Focus group: Small group who has been carefully screened or selected to be representative of a particular population group. Moderated discussion with focused questions to solicit opinions from participants.

Social media: Interactions with or posts from private citizens, representatives, or stakeholders on any social media platform (including, but not limited to, Facebook, Twitter, Instagram, Snapchat). The intent of the interaction must go beyond promotion. There must be a process for recording feedback and integrating it into the municipality's SCC application.

Written submission: An opportunity for citizens to prepare and submit open-ended written feedback.

Contest: The exchange of input from citizens for a opportunity to win a prize. Contest winners may be selected based on chance or skill. Prizes need not necessarily be monetary, they may be public recognition, goods, services, or experiences.

Citizen advisory role: Citizens act in an advisory role, but not directly involved in the core working group to develop the proposal (i.e. no decision-making power).

Interview: Any one-on-one discussion with a citizen. May be formal and structured or may be informal (e.g. at the post office in a small community).

Hackathon: A time-limited design competition where groups of citizens attempt to solve a defined challenge, typically through computer programming or other technology- or data-based solutions.

Workshop: Part consultation, part capacity building. Opportunity to work through a specific challenge.

Citizen representative on core team: A citizen who actively participates in the preparation of the application and who will be involved in the implementation of the project (i.e. shares decisionmaking power).

Planners in Public Spaces: A team of planners, or alternative individuals who are well-versed in the topic of concern, who are stationed in a public gathering space. They seek out interactions and input from members of the public who occupy that space.

Citizen panel: A large, self-selecting group of citizens who agree to provide feedback to the municipality or working group on an ongoing basis. A less involved form of participation than a citizen advisory role or being a citizen rep on the core team.

Updates/Information: Updates or information on the development of the municipality's application or on the SCC more generally are provided to the public-at-large through any means.

Stakeholder meeting: Meetings organized with existing stakeholder groups (organizations, working groups, etc.), discussion about their views. Stakeholders must act primarily in the public's interest for these meetings to be considered public engagement. 
Host conference: The organization of a professional or academic event which is open to the public. Education and the exchange of ideas are the main objectives.

Classroom activities: Public engagement activities run with students of any age, during standard teaching hours.

Call-in radio show: A live or pre-recorded radio programme that includes interviews by telephone with self-selecting private citizens about a topic related to smart cities, the SCC, or the municipality's application.

Art/Tactical urbanism: The production or display of art or an installation as a means to stimulate public discussion and input. Also includes creative writing. May be professionally commissioned or community-produced.

Kiosks: An electronic interface (for example via a tablet computer) in a public place that any citizen may interact with to gain information and/or provide input.

Tour: The process of organized group travel to or through a space as a means to stimulate public discussion and input.

Gamification: The application of typical elements of game playing (e.g. point scoring, competition with others, rules of play) to encourage citizen participation and input.

Internship/Work placement: Offering a paid or unpaid position related to smart cities, the SCC, or the municipality's application. Capacity building for the individual selected for the position is the primary objective.

Online activity: An engagement activity occurring on the world wide web. Internet connectivity and a device, such as a computer, tablet, or mobile phone is required to participate.

In-person activity: An engagement activity that occurs in real life. Proximity of participants is required.

Diversity and inclusion reflected in the design of public engagement: The deliberate use of methods to reach groups within a community who, for any reason, may not typically participate in public engagement activities. Common groups include youth, older adults, racialized communities, religious or cultural minorities, and people with disabilities, however this may vary based on the community context to include other groups.

Effort to reduce digital inequality: Removing the barriers to participation presented by low digital literacy and a lack of access to technology. Efforts must go beyond providing an analog alternative to digital engagement. Focus on capacity building. Help citizens with low digital literacy understand what smart cities are so they can provide informed opinions.

Geospatial information: Any information that is contributed by citizens which contains a locational marker (geotag). 
Stages of the innovation process: As defined by Desouza et al. in their 2009 article. 